Heibaum, Michael

Geosynthetics for waterways and flood protection structures controlling the interaction of water and soil

Verfügbar unter / Available at:

https://hdl.handle.net/20.500.11970/100674

Vorgeschlagene Zitierweise / Suggested citation:

Heibaum, Michael (2014): Geosynthetics for waterways and flood protection structures - controlling the interaction of water and soil. In: Geotextiles and Geomembranes 4 (42). S. 374-393. 
Erstveröffentlichung in Geotextiles and Geomembranes 42 (2014), S. 374-393. Für eine korrekte Zitierbarkeit ist die Seitennummerierung der Originalveröffentlichung für jede Seite kenntlich gemacht.

\title{
Geosynthetics for waterways and flood protection structures - Controlling the interaction of water and soil ${ }^{1}$
}

\author{
Michael Heibauma \\ a Tel.: +4972197263820. \\ E-mail address: michael.heibaum@baw.de. \\ BAW - Federal Waterways Engineering and Research Institute, Kussmaulst. 17, 76187 Karlsruhe, Germany
}

Article history: Received 9 March 2014, Received in revised form 2 June 2014, Accepted 3 June 2014, Available online 27 June 2014

The interaction of water and soil has been both a blessing and a curse in all times within living memory. Water is the origin of life but is also threatening life when appearing unboundedly. Therefore mankind has always worked hard to benefit from water resources on one hand and to deal with the threat of flooding on the other hand. For both, to protect the land and to allow for beneficial uses like irrigation or navigation, often special measures are necessary to keep the water within certain bounds. Structures to achieve a permanently stable situation like irrigation and navigational canals, river training or flood protection measures need suitable material, carefully thought out design and accurate execution. Often a decision has to be made among competitive approaches to optimize such structures. In many cases, geosynthetics can support or improve the functionality and sometimes only with geosynthetics the desired result can be achieved.

Geosynthetics can provide strength and flexibility, imperviousness and drainage, durability and robustness or controlled degradation. All these properties can be of use to handle the many occurrences of interaction of water and soil. Surface water has to be guided or to be kept off; percolating water should be controlled to avoid internal erosion effects should be restrained by appropriate filtration. To guarantee well functioning in general, also chemical and biological aspects have to be considered like ochre formation, root penetration and population by any kind of species. The German Federal Waterways Engineeringand Research Institute (BAW) has gathered experience with geosynthetics in hydraulic applications since more than 40 years. These years revealed the capabilities of geosynthetic solutions and simultaneously emphasized the need of careful selection, design and execution.

A large variety of geosynthetic fabric and structures is available. To control the interaction of water and soil many different attributes are required, e.g. membranes for impervious lining, filter sheets

\footnotetext{
${ }^{1}$ This is the Mercer Lecture.
} 


\section{Autorenfassung}

Heibaum: Geosynthetics for waterways and flood protection structures - Controlling the interaction of water and soil, 2014

for erosion control, different kinds of mattresses or wrap-around structures, voluminous elements from sandbags to mega containers for protection, training or immediate repair. In many cases geosynthetics can be designed to control the interaction of water and soil according to the individual and local requirements to allow for an excellent execution of waterways and flood protection structures.

Keywords: Geosynthetics, Impervious lining, Filter, Containment, Erosion, Scour

\section{Introduction}

We all remember the Great East Japan (undersea) Earthquake in March 2011. The earthquake triggered powerful tsunami waves that reached heights of up to $40.5 \mathrm{~m}$ and which, in the Sendai area, travelled up to $10 \mathrm{~km}$ inland. The hazard resulted in nearly 20,000 fatalities as well as over 125,000 buildings damaged or destroyed. And we remember similar event, the 2004 Indian Ocean tsuna$\mathrm{mi}$, triggered again by an undersea megathrust earthquake that hit several countries. With these and similar hazards, nature demonstrates the power of water. In such events, water does not only cause flooding, take lives and demolish goods but proves also to be stronger than soil, often even stronger than rock.

But leaving the coast and the valleys to the water and settling on hills or in the mountains would be no solution either. Water also comes from above. And if there is too much of it, again soil and rock are weaker than water. Hundreds of rain-induced landslides and mud avalanches in the world threatened lives and destroyed property. In any respect of human living - housing, farming, traveling and leisure - it is desirable to have water and ground in balance. Unfortunately this is not a persistent condition in many

\section{Heibaum: Geosynthetics for waterways and flood protection structures -} Controlling the interaction of water and soil. Geotextiles and Geomembranes 42 (2014), S. 375-393.

places of the world that are populated by mankind. No water prevents (human) life, but too much water as well. In the first case, water has to be transported from deep under the ground surface or from far away. In the second case, the water course has to be controlled.

Measures to control the water course need sufficient strength against water pressure and water flow. Soil and even rock have only a limited resistance against these hydraulic effects, therefore the interaction of ground and water is the main issue wherever water is or should be kept in certain bounds. Borders of surface water are the coast, river banks, canal embankments or dikes - so most confinement of water is made of soil and rock. Knowing the vulnerability of soil to water, mankind tried to improve its resistance against water since the beginning of settlement and building. Even 


\section{Autorenfassung}

Heibaum: Geosynthetics for waterways and flood protection structures - Controlling the interaction of water and soil, 2014

rock may not withstand the water forces: rock pillars at the Danish and the Australian coast vanished in comparably short time (Fig. 1).

But we are not powerless. The village Fudai in Japan was saved because a mayor ignored criticism and spent a lot of money on a gargantuan floodgate (Hosaka, 2011). In this manner, possibilities to control the interaction of water and soil can be found in many cases. Certainly, we need careful planning and intelligent design in each individual case. The floodgate in Fudai was the right solution for the rather narrow valley and would not match in a plain. So we should always try to find the matching solution - sometimes it needs intricate tracks to reach one's goal.

\section{Interaction of water and soil}

\subsection{Actions}

Currents and waves come into mind when thinking of hydraulic loads in rivers and at the coast. Therefore, at first sight canals appear to have the benefit of no flow like in rivers and so one reason

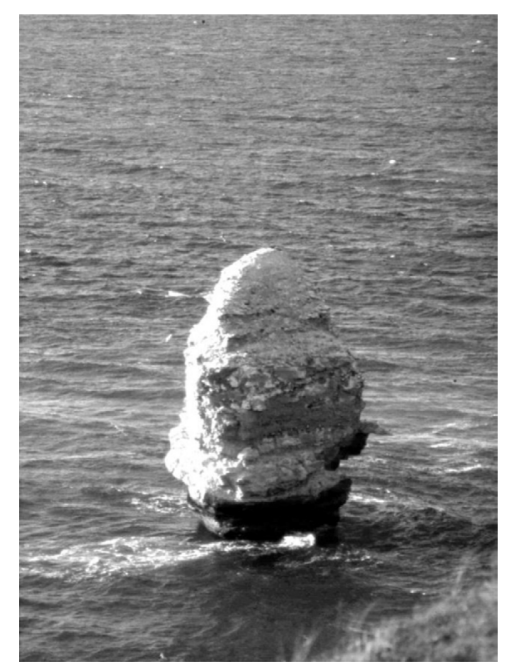

Fig. 1: $\quad$ Skarreklit, Denmar, vanished 2005.

of erosion and scour seems to be omitted. But we must not forget the ships that can create heavy loads on the bank. Propeller and bow thruster jets as well as return current and transversal stern wave possess strong erosive energy, which asks for an appropriate protection.

In rivers and at the coast there is the risk of flooding. Due to water levels high above the normal there is interaction of water and soil in areas where it is not expected. Therefore, protection measures should be discussed also for extreme and rare events. Even seemingly mild hydraulic load from rainfall can be the reason for severe impact on structures and ground. Surface erosion is an 


\section{Autorenfassung}

Heibaum: Geosynthetics for waterways and flood protection structures - Controlling the interaction of water and soil, 2014

extraordinary threat to all earth structures, because initially only tiny rills can develop to deep gullies or channels, which can reduce their stability. And intense rainfall can be the reason for hill slides and mud avalanches.

Furthermore there is a kind of flow we cannot see: groundwater and seepage water percolating through the ground and the earth structures. From unexpected and unwanted "springs", we can suspect the (often negative) interaction of percolating interstitial water and soil, which might result in sand boils, liquefaction, piping or internal erosion. To get more information on such interstitial flow, we can try to model it, either physically or numerically, but we never can be sure to know all about it. We only can hope to get enough information to plan countermeasures.

\subsection{Countermeasures}

So what can we do against such unwanted effects? To mitigate the detrimental interaction of water and soil, either the action or effect of the water has to be reduced or the resistance of the ground has to be increased. The first could be addresses as "active" measures while increasing the resistance is a "passive" method.

Active methods are all measures that alter the flow pattern (of surface water as well as of pore water) or to reduce the wave intensity. Also limiting the hydraulic gradient or avoiding excess pore pressure would reduce the effect on the ground. Structural measures to alter the surface flow pattern are elements to divide the runoff, check dams and river and coastal training works like sills, breakwaters, groins or longitudinal dikes. Drains affect the pore water flow to avoid internal and surface erosion. They also can help to prevent excess pore water pressure and thus the risk of fluidization. Impervious elements prevent any interaction of ground and water. Active measures are dealt with in the sections "Keep the water away", "Control the interstitial water" and "Direct the surface water". Active measures might be the more intelligent way to influence the interaction of ground and water, but often the situation in situ compels to other solutions, in particular if we are confronted to deluge-like quantities of water.

Increasing the resistance is the alternative and often the only measure if no alteration of actions can be realised. Also the comparison of costs may lead to such a decision. Strengthening the ground comprises an increase of the overall stability of an earth structure or an increase of the resistance of the single element that is affected by hydraulic action. Passive measures are dealt with in the sections "Strengthen the structure and the ground" and "Protect the surface againsthydraulic impact". 


\section{Material}

\subsection{General}

Discussing geosynthetics for waterways and flood protection covers a large variety of material. Many kinds, woven and nonwoven, extruded mats and grids as well as impervious products like polymeric and bentonite membranes are used in the various

Heibaum: Geosynthetics for waterways and flood protection structures Controlling the interaction of water and soil. Geotextiles and Geomembranes 42 (2014), S. 375-393.

applications. When discussing the interaction of soil and water, permeability is a major issue. Geosynthetics offer the whole range from nearly no obstruction to fluid flow to technically impermeable. All the major functions of geosynthetics, separation, filtration, drainage, reinforcement, barrier, containment and protection are needed for successful serviceability of the structures discussed in this context.

Installed as a separator, a geosynthetic prevents intermixing of adjacent soil layers with different properties during construction and the projected serviceperiod. Usually applied in dry structures, it is installed in cases with soil-water-interaction when filter function is not required, e.g. separation of a granular and a cohesive soil body of high plasticity. Woven and nonwoven fabric is used for that purpose. Utilized as a filter the geotextile allows for adequate flow of fluids across its plane while preventing the migration of soil particles with the flow. The use of woven or nonwoven for that function will be discussed in Section 5.5. Filter function is also provided by so called silt curtains, i.e. a geosynthetic - mostly a woven fabric - placed across the path of a flowing fluid carrying fine particles in suspension with the aim to retain some or all particles, while allowing the fluid to pass. Fluid transmission or drainage function offers a geosynthetic that allows for adequate flow of fluids within its plane. To achieve this, thick nonwovens or composites of an extruded drainage layer, sandwiched by filter layers are installed. A geosynthetic may also act as a fluid barrier function. Polymeric membranes or geosynthetic clay liners can be considered as technically impermeable for the majority of applications.

For some applications we need to strengthen the soil. A geosynthetic provides reinforcement function by increasing the strength of a soil mass by carrying tensile loads, and thus maintaining the stability of the soil mass. Brian Mercer, to whom this lecture is dedicated, was one of the first to believe in the capability of geosynthetic products. His invention of the process from a molten polymer to the final plastic net was the basis of the development of reinforcing grids. Counter-rotating dies at the same speed created a mesh in a diamond shape. Other processes followed and today 


\section{Autorenfassung}

Heibaum: Geosynthetics for waterways and flood protection structures - Controlling the interaction of water and soil, 2014

there are several systems available. Besides the well-known reinforcing grid, randomly distributed fibres within the soil mass can be used to increase the strength of the soil. In some applications, polymeric or bituminous membranes need a protection or cushioning layer to prevent damage. Often a nonwoven is used to control and eventually to damp dynamic mechanical actions. Geosynthetics used as containment allow for numerous applications dealing with the interaction of water and soil. A geosynthetic may encapsulate any civil-engineering-related material such as soil, rock or fresh concrete and prevent its loss. Containments can be manufactured to nearly any specific geometry, as for example cubes, tubes or mattresses. Wovens and nonwovens are used. A special application is rope gabions.

\subsection{Robustness}

Whenwe are talking about earthworks and hydraulic structures, we must be aware that there is made use of heavy machines and heavy elements, which asks for appropriate robustness. Geosynthetics can provide the necessary robustness, which can and must be proven by tests. What does robustness mean? One concern is that the geotextile survives the impact of any material, e.g. armour elements that are dropped upon the sheet. BAW developed already in 1978 an impact or drop test (BAW, 1978; currently relevantissue: RPG, 1994), through which the geosynthetic fabric has to prove that it survives the impact of an armour stone falling through the air (Fig. 2). This is

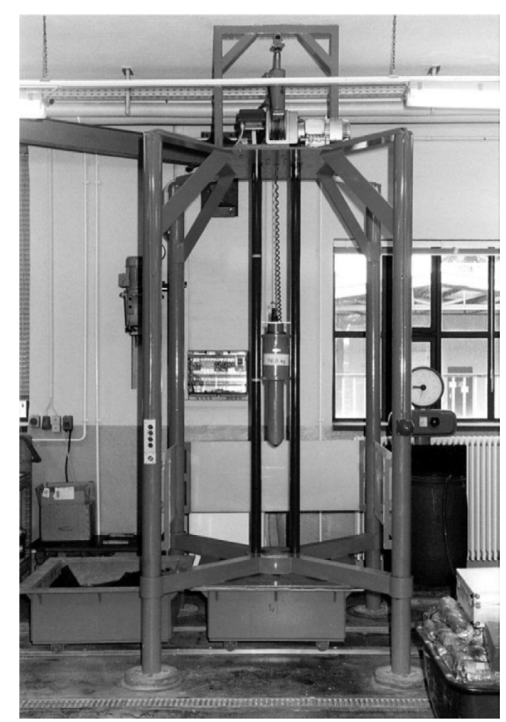

Fig. 2: $\quad$ BAW impact test.

a frequent load for a geotextile used in revetment systems. To simulate this load definitely, a drop hammer with a tip of defined geometry is dropped onto a geotextile sample placed on a test soil (medium dense sand) at determined drop energy. The drop energy is chosen according to the stone size used for the revetment. Perforations (holes) and any visible changes indicating a reduction of the filter function and strength, e.g. damage to the weft and warp threads or displacement of 


\section{Autorenfassung}

Heibaum: Geosynthetics for waterways and flood protection structures - Controlling the interaction of water and soil, 2014

threads, are regarded as damage. Even though it looks like a test hard to survive, the majority of nonwovens with a unit weight of $600 \mathrm{~g} / \mathrm{m}^{2}$ or larger and a number of wovens survive the test with a drop energy of 600-1200 Nm. For applications beyond the use in inland waterways, the weight and drop height of the hammer may be adapted to the boundary conditions on site. Another robustness issue is the resistance against abrasion to withstand installation stress, moving sediment or rocking armour stones. An appropriate test has to take into account the often nonstatic contact of soil and geotextile. Soil and rock particles do not behave like a rigid surface, but roll, tumble, rock or draw off. Therefore tests like the "sliding block method" for geotextiles (ASTM D4886-10 or ISO/DIS 13427:2013) do not represent the interaction of soil or rock and geotextile. To simulate better the conditions in situ, a special test was developed by BAW to take into account the abrasive load induced by the hydraulic processes on the bank and bottom of waterways. The "rotating drum test" (RPG, 1994) was developed for geotextile filter layers beneath riprap (Fig. 3). The single armour stone always has some space that allows rocking movements under hydraulic loads which can abrade the fabric. This test proved also suitable to check the resistance against abrasion of geotextiles that are not protected by armour and loaded by sediment and bedload transport. Recovered

Heibaum: Geosynthetics for waterways and flood protection structures Controlling the interaction of water and soil. Geotextiles and Geomembranes 42 (2014), S. 375-393.

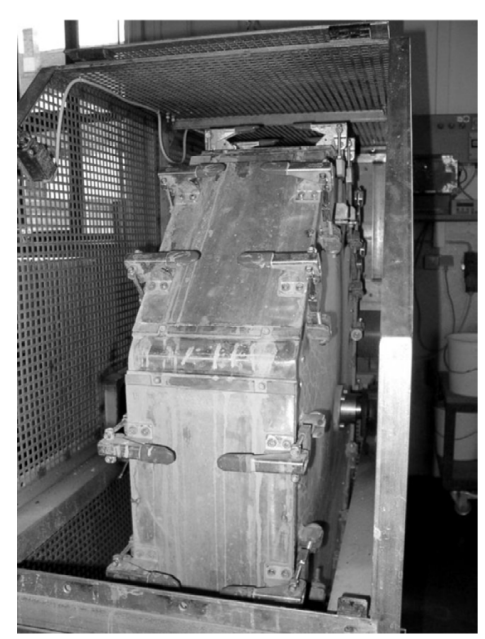

Fig. 3: $\quad$ BAW rotating drum test.

samples proved the similarity to fabric that was tested in that device. In this test, a mixture of stone chippings and water passes over geotextile samples installed in a rotating drum. The standard test comprises two abrasion phases at $16 \mathrm{rpm}$ of 40,000 revolutions each, changing direction every 5000 revolutions. If the samples are not degraded after the first 40,000 revolutions (visual inspection) new stone chippings are filled in (because the chippings are well rounded after that process) 


\section{Autorenfassung}

Heibaum: Geosynthetics for waterways and flood protection structures - Controlling the interaction of water and soil, 2014

and the second phase is carried out. If the samples have not been destroyed after 80,000 revolutions, samples are taken and their tensile strength is tested. A geotextile is considered resistant to abrasion loads if $75 \%$ of the required tensilestrength is kept after execution of the test. Since some fabric still shows significant tensile strength even though there is no filter function due to holes in the fabric, the remaining opening size is checked additionally (Fig. 4). It has to be proved

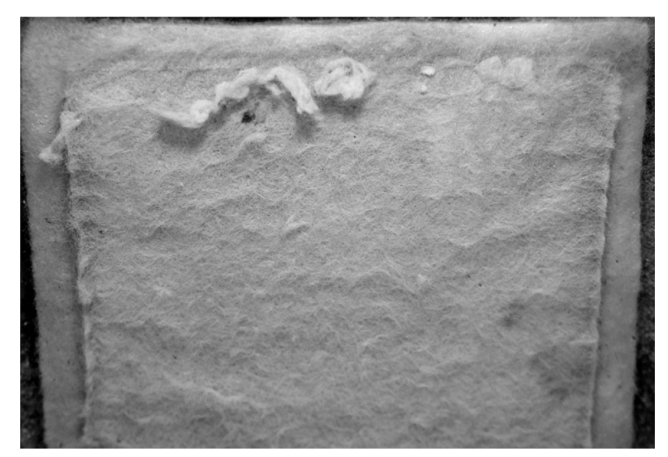

Fig. 4: $\quad$ Sample after 80,000 revolutions in the rotating drum test.

that the filtration capacity has not changed in an unacceptable manner, i.e. the opening size should not increase more than an appropriate limit value. There are a large number of nonwovens and some wovens that survive this test with nearly no damage. But there is also numerous fabric degraded to pieces after only 40,000 revolutions.

Robustness also means durability, since we want a long-term reliability of the structure with all its elements.

Systematic application of geotextiles in hydraulic applications started in the 1960s. Excavations from these first structures show that we can rely on the durability of geosynthetics. (Certainly there has to be an individual design in each case!) Nevertheless, there are few instructions to date how to prove durability for 50 or 100 years. A state of the art report is given by Greenwood et al. (2012).

The demand for durability hinders the application of natural fibres. Such fibres will degrade after a certain time. But use can be made of such material if only for a limited time, e.g. during the growth of newly planted vegetation for erosion prevention. If the plants are able to provide full protection, no additional support may be necessary. But often it is preferable to leave the geosynthetic erosion protection in place even with grown up vegetation. 


\section{Keep the water away}

\subsection{Structural conceptions}

There are two ways to keep the water away: building retaining structures or elevating the ground to a level that won't be reached any more by the water. Retaining structures are usually embankments either to confine a water course (e.g. to guide the water in a canal) or to hinder water access by building dikes.

NB: The terms dike and levee are often used interchangeably. In other places a dike is called a structure to divert or retain flood water from tidal bodies of water, while a levee diverts or retains floodwaters from streams and lakes. In the following, the term dike will be used for both kinds of structures.

In many flood-prone countries, like for example in Bangladesh, people are advised to raise the ground before building housing (ADPC, 2005). This principle can be followed as well for temporary use during a construction process. To build a new bridge in the dry, in Korea the sea bed was elevated to allow for better building conditions (Yee and Choi, 2008). The geosynthetic tubes were used to confine a certain area which then has been filled up. Afterwards it was easy to remove these elements and the fill.

If stilts are used to keep the house above flood level, one must not forget that the ground around the stilt foundation has to be scour protected. A reliable method is to use containers with ca. $1 \mathrm{~m}^{3}$ fill. Such elements are in many cases heavy enough, not to be transported by the current. The fabric used should be chosen as a filter towards the fill and towards the ground material. To provide shelter against UV radiation, the containers should be covered by sand or top soil that could be easily replaced after a flood.

In Japan there is put substantial effort on raising the riparian ground to provide flood safety. Instead of dikes with still a flood threatened hinterland, all the area should be elevated to so called super levees. "A super levee is an especially wide embankment built in cooperation with riverside urban redevelopment projects. It assists in effective land usage, the strengthening of earthquake countermeasures, the development and maintenance of a healthy river environment, and the improvement of the urban environment." (ANMC21, 2009) Meanwhile a number of such flood prevention measures are built or planned (Ara, 2012; Tsuchiya, 2010; Agency, 2010).

All these structures have to cope with the interaction of water and soil. Even though they should be build high enough, there still 


\section{Autorenfassung}

Heibaum: Geosynthetics for waterways and flood protection structures - Controlling the interaction of water and soil, 2014

\section{Heibaum: Geosynthetics for waterways and flood protection structures - Controlling the interaction of water and soil. Geotextiles and Geomembranes 42 (2014), S. 375-393.}

remains a certain risk of inundation or overtopping, thus creating potential for erosion. Often the subsoil includes permeable layers that allow undersea page of the embankment or dike. And generally the raising water level will cause saturation and percolation of the ground, incorporating the risk of internal particle transport. To hinder such effects, impervious linings can be installed. But only in canals, where the lining covers the whole wetted surface, full protection can be achieved. In all other cases, there is always the chance of water flow around the edges of the lining at the top, at the toe and at the sides. Therefore such lining will always be only a partial protection, e.g. in reducing the gradient or extending the time until water will reach the downstream side of the structure.

The use of geosynthetics in embankments and dikes is manifold. Products for impervious lining are available. Geosynthetic containments like bags, tubes or containers provide, if needed, beside the encasement of a certain soil mass simultaneously erosion protection and filter function. And last but not least, geosynthetic reinforcement will increase the general strength of earth structures.

\subsection{Impervious linings}

\subsubsection{General}

For many hydraulic structures like embankments, waterways, dikes etc. there is a need to hinder infiltration or percolation. What sounds simple is an ambitious task since water uses every micro opening to seep through. Therefore we have to consider overtopping over the top edge of the lining, underseepage of partial linings and percolation wherever possible.

Impervious linings have been used since $1300 \mathrm{BC}$ (Wölfel, 1990). In these first documented cases, our ancestors took bitumen to line water courses. The material was forgotten for a long time and recovered only in the sixteenth century, and used as building material only in the nineteenth century. Bitumen is still used for impervious linings of water courses. About $10 \%$ of the membranes that we use today are bituminous linings, $90 \%$ are polymeric membranes. Additionally we use geosynthetic clay liners (GCL), which sometimes are counted as membranes, sometimes not. In the following, membranes are bituminous or polymeric exclusively.

Both, membranes and GCL have the advantage of being flexible. In case of deformations of the subsoil, the lining is able to follow, provided that the armour (if applied) is flexible as well. Other impervious linings like concrete slabs, concrete mattresses or asphalt layers are too stiff to adjust to subbase deformations. They will bridgeindentations caused, e.g. by sub-erosion and thus no warning is given until a cavity under the lining has become too large and the whole structure collapses. 


\section{Autorenfassung}

Heibaum: Geosynthetics for waterways and flood protection structures - Controlling the interaction of water and soil, 2014

\subsubsection{Membranes}

The use of geomembranes related to hydraulic structures started in Europe with dams. The first well-documented case is the Contrada Sabetta dam in Italy, lined with a polyisobutylene geomembrane covered with concrete slabs in 1959. Tests conducted after 39 years in service showed satisfactory behaviour of the geomembrane itself (Cazzuffi, 1999). Geomembranes are increasingly used in ponds and in canals for the transport of water (irrigation, drinking water, electricity production) as well as for navigation. The size can vary enormously, from small irrigation canals to large projects such as the Kimberley Canals in Australia (Kelsey, 2005) which in the end was decided not to be build. Another importantapplication are rain retention basins to reduce the runoff and to hinder flooding downstream (Fig. 5).

Geomembranes are placed with or without a protection layer. Exposed geomembranes cause lower costs, are quicker and easier to install, cannot be damaged by installing a cover layer, are easily inspected visually and repaired if necessary, allow for shorter intervention times. But they have also some disadvantages: lower durability of the geomembrane which is exposed in particular to UV radiation, risk of mechanical damage by vandalism, floating objects, falling objects, ice, mechanical effects of wind and waves. Several evaluations show that the performance of synthetic liners without a protection varies dramatically, while protected membranesare rated excellent in all cases (Karimov et al., 2009; Bonaiti et al., 2011). On the other hand, inflexible protection like shotcrete on a membrane is susceptible to erosion underneath the lining because of bridging erosion channels (Bonaiti et al., 2011).

The main advantage of installing an armour is the protection of the geomembrane against the external effects mentioned above, thus providinggreater durability. On the other hand, consideration must be given to the risks of puncturing the geomembrane when installing the cover layer, to difficulties of access to the geomembrane in case of a leak (detection and repair) and to the costs. Swihart and Haynes (2002) consider a concrete-covered membrane as the lining with the highest effectiveness because the geomembrane provides the water barrier and the concrete protects the geomembrane from mechanical damage and weathering. They assume a lifetime of 40-60 years for the protected lining and only 10-25 years for the exposed membrane. As stated above, flexible armour should be preferred to avoid bridging cavities and erosion below the lining.

A major concern is the puncturing resistance of the geomembrane during construction. Therefore, often extensive tests in the laboratory and on site have to be performed prior to installation (Heibaum et al., 2006). A guide to such tests on site has been written by the French Chapter of the IGS (CFG, 2001). If subbase or armour material is angular and/or large-sized, a thick puncture resistant geotextile (mostly nonwoven $500 \mathrm{~g} / \mathrm{m}^{2}$ ) or an appropriate granular layer should be placed between geomembrane and subbase or armour. The International Commission on Irrigation and Drainage (ICID) confirms the growing use of geomembranes in irrigation channels (Plusquellec, 2004). There it is suggested that covering the geomembrane is desirable because irrigation channels cannot be protected from access by the public or animals, and they require maintenance operations (removal of sediment, for example). 


\section{Autorenfassung}

Heibaum: Geosynthetics for waterways and flood protection structures - Controlling the interaction of water and soil, 2014

Intake channels for hydroelectric power production are another field in which geomembranes are used. Strobl et al. (2002) and Schaefer (2006) present a comparison between the traditional sealing methods (cement and asphalt concrete) and polymeric and bituminous geomembranes for the rehabilitation of canals lined with cement concrete. The main advantages of geomembranes are: time savings on installation, lower costs, and no reduction of the cross section. Furthermore, exposed linings exhibit lower flow resistance than membranes protected by rough material, resulting in a higher energy potential for conversion into electric energy. The expected lifetime of the geomembrane solution is estimated in this kind of application to be higher than 30 years (experience value observed); the value given for the traditional solution is ca. 50 years.

Since about 20 years the use of geomembrane liner systems is to replace the traditional methods for rehabilitation of French navigation canals. The navigation canal network in France was designed in the late nineteenth century. Only a few structures of larger dimensions have been built since the 1950s. The embankments of older canals were always built using the materials available on site after more or less careful selection. They are now showing signs of age, in particular leaks, failures and erosion phenomena, which need repair and improvement. The traditional improvement techniques consist in building a vertical tightness screen inside the body of the canal embankment (sheet piling or grout curtain) or in

\section{Heibaum: Geosynthetics for waterways and flood protection structures -} Controlling the interaction of water and soil. Geotextiles and Geomembranes 42 (2014), S. 375-393.

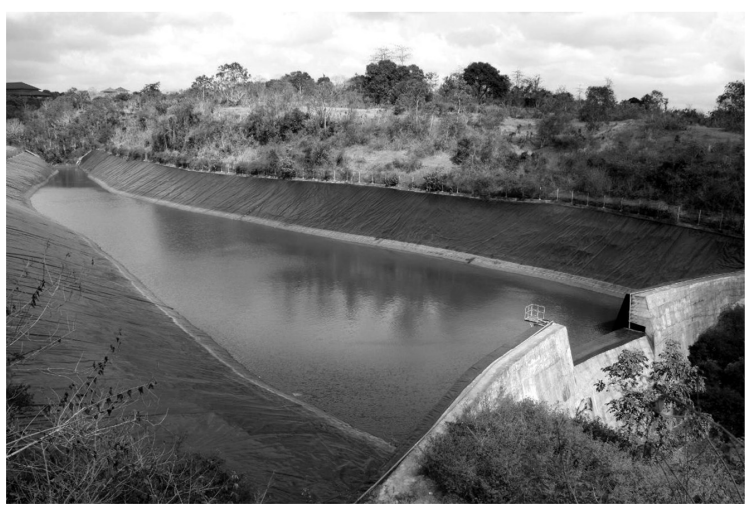

Fig. 5: $\quad$ Udayana rain water retention basin, Indonesia.

installing a watertight surface coating (cement concrete or asphalt concrete). Increasing use is made now of installing a new membrane lining - in France, bituminous membranes are rather common - in most cases covered by a concrete protection layer. Among the numerous standards existing all around the world concerning geomembranes (physical, hydraulic and mechanical properties, durability,...), only two European Standards shall be mentioned that specify the relevant 


\section{Autorenfassung}

Heibaum: Geosynthetics for waterways and flood protection structures - Controlling the interaction of water and soil, 2014

characteristics of geomembranes to be used for reservoirs and dams (EN 13361, 2013) and for canals (EN 13362, 2013). These standards specify also the appropriate tests methods to determine certain characteristics, but do not give limit values. In particular, they enable the designers to define the characteristics applicable for a given project.

Placement of membranes is usually done in the dry because the single sheets have to be welded to form a functioning impervious lining. With a certain effort it is also possible to place a membrane lining in the wet by lifting the membrane out of the water onto a pontoon, welding the sheets there and drowning it again. But in such cases it needs detailed quality control in respect of proper imperviousness and throughout close contact of membrane and subsoil. A case history also reports on glueing a PVC membrane below the water table (Rohe, 1991).

When discussing geomembranes, one of the biggest nonsense must be mentioned what can be done using membranes in flood protection measures:rolling membrane sheets onto the upstream side of a dike into the water. The idea is that the polymeric sheets shall reduce the water infiltration into the dike. But since the overlap will never be tight and the lower end can't be connected to an impervious layer, the outcome is zero (only the supplier of the membranes has a profit). Actually, rolled on geomembranesare no help to increase dike stability in such situations! To prove this fact, Brauns et al. (2003) performed tests in an appropriate facility, where the percolating water could be measured. The result: zero effect! That's no geosynthetic solution - that's no solution at all!

\subsubsection{Geosynthetic clay liner (GCL)}

Geosynthetic clay liners - or according to EN ISO 10318 "clay geosynthetic barrier (GBR-C)" - have been installed in many applications, predominantly as impervious linings of landfill covers and for groundwater protection purposes in road and runway construction.In hydraulic applications it can be found as lining (initial or repair) of irrigation and retention ponds, canals and dikes.

A common application of GCL is the use as an impermeable surface lining of dikes. After several dike failures in Middle Europe, GCL were considered for repair or improvement. It was proposed to line the water side of the dike with a GCL to hinder or at least reduce the percolation of water through the dike. But installing just a lining on the water side of the dike may not result in the desired effect. The main problem is the contact to an impervious soil layer at the upstream foot of the embankment. If the water is able to flow below the lining into the dike, the effect of the lining will be negligible. The seepage line in the embankment will reach nearly the same level as without the lining. The only advantage is to gain some time until this condition is reached, depending on the permeability of the embankment. If there is no soil layer with low hydraulic conductivity at the foot of the dike, additional measures are necessary, e.g. a seepage screen to a sufficient depth. Usually grout injection or steel sheet piles are used to achieve the desired seepage reduction, but also plastic sheet piles have been used with success for that purpose.

The use of GCL on dikes has no long tradition - the first applications in Germany took place in the 1990 s. To learn more on the serviceability of such solutions, several excavations have been executed (Fig. 6) to check if after 3-10 years of service the GCL are still in perfect shape (Fleischer and 


\section{Autorenfassung}

Heibaum: Geosynthetics for waterways and flood protection structures - Controlling the interaction of water and soil, 2014

Heibaum, 2010). The results confirm that GCL are an appropriate solution. Only roots can create problems which will be discussed later.

The use of GCL in a navigation canal is even younger. There are significant differences between the application of bentonite mats in dikes and in navigation canals. The linings of navigation canals are always submerged, while the liningsin dikes are only subjected to hydraulic loads when water levels are high. This affects especially the installation of the GCL. The lining of navigation canals and sometimes also of other water courses where complete discharge is not possible, has to be installed under water. In navigation canals it is complicated by ongoing shipping. Usually these linings are covered with a protective layer of riprap. By contrast, dike linings are installed under dry conditions and the protective layer comprises mainly sand or gravel.

When installing a GCL, the overlap needs special treatment. Usually bentonite powder is spread in the overlap and the seam is

Heibaum: Geosynthetics for waterways and flood protection structures Controlling the interaction of water and soil.

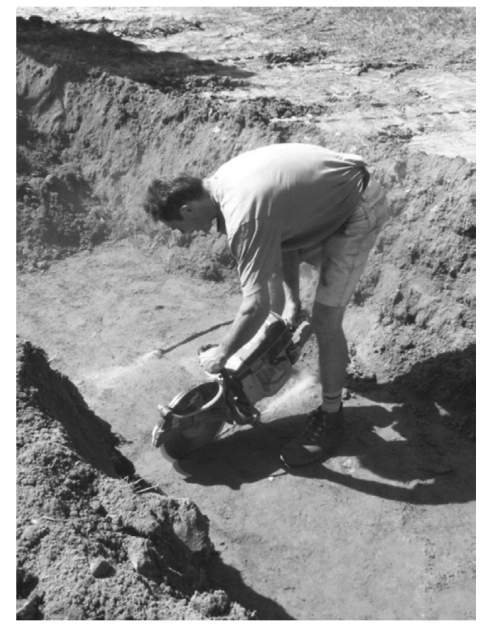

Fig. 6: $\quad$ Recovering GCL from dike.

sealed with bentonite paste. Such after-treatment is not possible when the GCL is to be placed under water. To avoid any aftercare of the seam, either the overlapping areas of nonwovens are bentonite-impregnated or suitable woven fabric is used. This way, no transmission flow in the overlap is possible. Although GCLsin dikes are installed underdry conditions, bentonite-impregnated fabric should nevertheless be specified also for this application to rule out any need for subsequent sealing of the overlap as the quality of the overlap may suffer if bentonite mats on slopes are stepped on. 


\section{Autorenfassung}

Heibaum: Geosynthetics for waterways and flood protection structures - Controlling the interaction of water and soil, 2014

Two installations in the wet have been executed in Germany in 1997 and 2000. Both installations have been and are still accompanied by extensive monitoring (Fleischer and Heibaum, 2002). The liner used in Germany consisted of a base woven geotextile, a sodium bentonite fill of $4200 \mathrm{~g} / \mathrm{m}^{2}$ and a cover nonwoven. To provide immediate ballast, because a GCL alone would float in the water due to the air entrapped in the fabric and in the bentonite layer, a second geocomposite, namely a 'sandmat' with $8000 \mathrm{~g} / \mathrm{m}^{2}$ of sand in between two nonwovens was chosen to ballast the GCL. GCL and sandmat are placed in one action. Both the GCL and the sandmat were rolled up together on a steel tube, but staggered $80 \mathrm{~cm}$ (Fig. 7). The placement has been done by a lattice trolley boom with a vertical lattice mast and a hydraulically driven spreader bar. That device enables installation to a depth of more than $20 \mathrm{~m}$. For the second installation sandmat and GCL were combined to one single geocomposite of three geotextiles and a layer of sand in between the upper two sheets and the bentonite layer in between the lower sheets. The system of (bottom up) woven base, bentonite layer, intermediate nonwoven, sand layer and top nonwoven was bonded by needle punching.

A later project, the lining of a drinking water canal in the Ukraine, put into action the lessons learned from the two above projects. This canal cannot be closed being the only water supply for the Donetsk Basin. To repair the leaking concrete lining, a new impervious layer was needed, but with limited thickness only, not to reduce significantly the channel's cross section. The solution chosen was to place a GCL upon the existing surface (under water) and to build a protection layer from prefabricated concrete slabs with spacersto hold them with a gap above the GCL and then to fill the gap with concrete (Werth et al., 2010).

As a result of the pilot projects in Germany, general requirements and design specifications for such applications have been established (EAO, 2002). A special requirement is a sufficient resistance against impact forces. When riprap is dropped upon the GCL, it is not a question of damage of the geotextile, but the bentonite which has started to swell already, can be locally displaced, leading to increased permeability at this spot. For that reason armour stones have to be laid on the GCL with care. Additionally, high resistance against erosion under the conditions of a navigable waterway is necessary to maintain the imperviousness. Tests showed that neither high gradients nor dynamic hydraulic loading (unsteady and reversing flow) will erode the bentonite from the GCL applied in these cases. Fleischer and Heibaum (2008) discuss the requirements and appropriate tests for the application of GCL in waterways. The Federal Waterways Engineering and Research institute in Germany (BAW) has issued guidelines for testing flexible imperious linings (RPW, 2006). For testing the hydraulic conductivity of GCL, a European standard was issued only recently (EN 16416, 2013).

Only roots can cause trouble! Geosynthetic fabric and bentonite layer can be penetrated by roots (Fig. 8). As long as the roots are alive, imperviousness is not affected. But when dead, it's only a bundle of fibres into that the bentonite cannot penetrate, so increased hydraulic conductivity will be observed. So for installation in waterways, an additional protection layer is necessary in the zone of fluctuating water level, where vegetation can develop. Usually dikes are not covered by trees, at least they should not be. But also GCL in grass-covered dikes may suffer root penetration, when big trees are near the foot of the dike or other deep rooting vegetation has grown up. 


\section{Autorenfassung}

Heibaum: Geosynthetics for waterways and flood protection structures - Controlling the interaction of water and soil, 2014

There is a third solution of impervious lining incorporating geotextiles: the concrete mattress. A base and a top sheet of fabric (mostly woven) can be sewn together to form a continuous mattress, which is filled with concrete. Constant thickness is kept by spacers woven in the two fabrics. The concrete provides the impervious lining, while the fabric is not only the envelope but also reinforcement. While the outer cloth may be weakened by weathering, the inner cloth is well protected. Concrete mattresses are successfully applied e.g. to repair leaking old concrete or asphalt linings. But we have to recognize that this is a non-flexible solution that can undergo brittle failure, if there is significant deformation of the subbase and can suffer cracking which increases the permeability.

\section{Control the interstitial water}

\subsection{Slope stability}

If water penetrates into the ground, it is impossible to follow its flow path, and consequently any effects of percolating water can't be defined accurately. As a first effect, the state of the soil changes from unsaturated to saturated resulting in a decrease of effective stresses due to buoyancy and in the loss of apparent cohesion and thus in a loss of stability of the soil skeleton. In unsaturated condition, water menisci form at the grain contacts and the surface tension of the interstitial water causes negative capillary pressure. This creates interparticle forces that form the matric suction stress. Since the moisture content often is not uniform, also these forces are non-uniformly distributed. Apparent cohesion, respectively matrix suction contributes to the shear strength of the soil, an effect

Heibaum: Geosynthetics for waterways and flood protection structures Controlling the interaction of water and soil. Geotextiles and Geomembranes 42 (2014), S. 375-393.

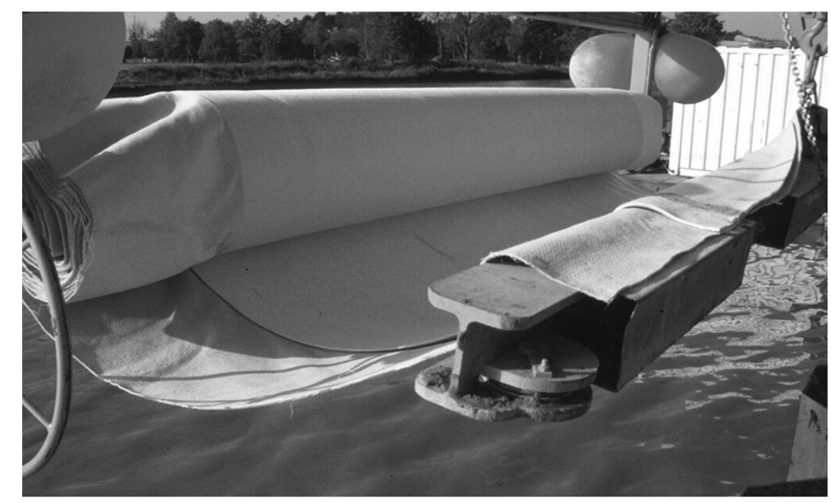

Fig. 7: $\quad$ Rolled up GCL and sandmat. 


\section{Autorenfassung}

Heibaum: Geosynthetics for waterways and flood protection structures - Controlling the interaction of water and soil, 2014

that diminishes with increasing water content. Insofar it has a significant influence on slope stability (Calo et al., 2011) and such also on dike safety. Gruber (2008) reports for example that even a well-designed reinforced slope failed due to the fact that the fill became saturated and its shear strength was reduced. Additionally erosion at the toe caused loss of support and increased the damage. Such cases teach not to take into consideration apparent cohesion for stability analysis in earth structures, because this parameter is too much dependent on the water content and is completely lost when the structure is saturated.

If the water content and the hydraulic gradient are high enough to develop percolation of the soil skeleton, additional flow forces act inside the soil body. Since we can't look inside the soil body, certain assumptions are necessary to calculate these forces. Firstly, the flow path has to be defined that is strongly dependent on the local hydraulic conductivity and pore structure. Capillary effects can impinge on the flow regime. Capillary barriers make use of these effects by purpose. Certain assumptions are inevitable to model the internal flow pattern. Fortunately, rather sophisticated numerical models are available to illustrate the water migration inside a soil body rather realistically. A first indication of unwanted percolation of dikes or other sloped earth structures can be sand boils at the toe or water exiting on the slope.

A first countermeasure must be to hinder any sediment discharge and any surface erosion caused by such "springs". A first countermeasure can be to dam the exiting water of a sand boil

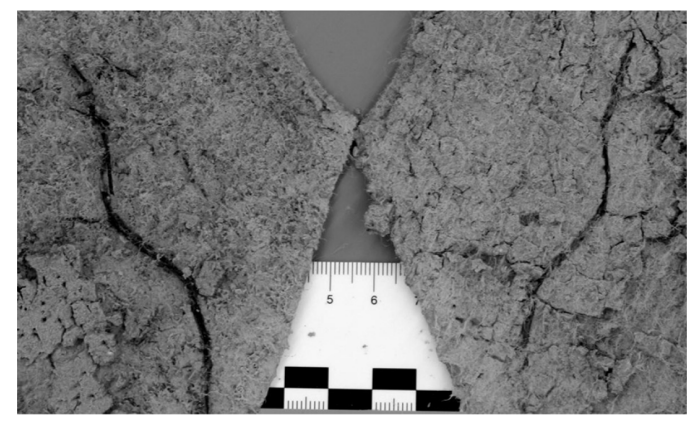

Fig. 8: $\quad$ Fold out GCL sample with penetrated root.

to avoid excessive material transport and to reduce the gradient. This can be done by building a ring dike of sandbags ("boil ring") - a simple but effective use of geotextile elements that is common all over the world as a first emergency countermeasure (Fig. 9). A "spring" on the slope should be covered by a filter and a certain surcharge to prevent erosion but to allow draining - nonwoven sandbags filled with gravel or coarse sand would be ideal since both filter and weight is provided. If support is needed against imminent slope failure, a load of filtering (!) sand bags at the toe and rows of sandbags up the slope are sustaining measures.

The best countermeasure would be to hinder water exiting in general. If any susceptibility of sand boils is known, relief wells or drainage trenches could be installed. To avoid water exit on the 


\section{Autorenfassung}

Heibaum: Geosynthetics for waterways and flood protection structures - Controlling the interaction of water and soil, 2014

downstream slope of a dike, a trench drain can be installed at the toe or the whole dike toe is built as a drain. This way the interstitial water flow is directed to it and won't reach the slope surface. The important aspect of a well-functioning drain is to create a large filter surface. For that purpose, a sufficiently large trench is lined by a filter fabric and filled with highly permeable fill material, with or without an additional drain pipe. It should be avoided just to wrap a filter fabric around a drain pipe!

\subsection{Landslides}

Landslides are primarily triggered by water, less by earthquake or by other mechanical mechanisms. Intense rainfall, rise in groundwater within the slide, snowmelt, flooding, or other inundation of water resulting from irrigation, or leakage from pipes can be the reason. Landslides threaten housing and all traffic routes, roads as well as railways and waterways. The latter may be affected twofold: (1) triggering inundation due to the displacement of water by the slided mass and (2) blocking the waterway. In case (2) the landslide will act as a natural dam, blocking the flow of the river and creating flooding upstream. Such dams are often composed of loose, unconsolidated material, that may easily be eroded by percolation (internal erosion) or overtopping (surface erosion) which may result in breaching. If breaching happens, the backed-up water rushes down the waterway, potentially causing catastrophic downstream flooding. Case histories are reported by Highland and Bobrowsky (2008).

Therefore preliminary measures to control the interaction of water and soil should be undertaken, if the possibility of such mass failures is suspected. Brumley (1978) proposes to reduce the

Heibaum: Geosynthetics for waterways and flood protection structures -

Controlling the interaction of water and soil. Geotextiles and Geomembranes 42 (2014), S. 375-393.

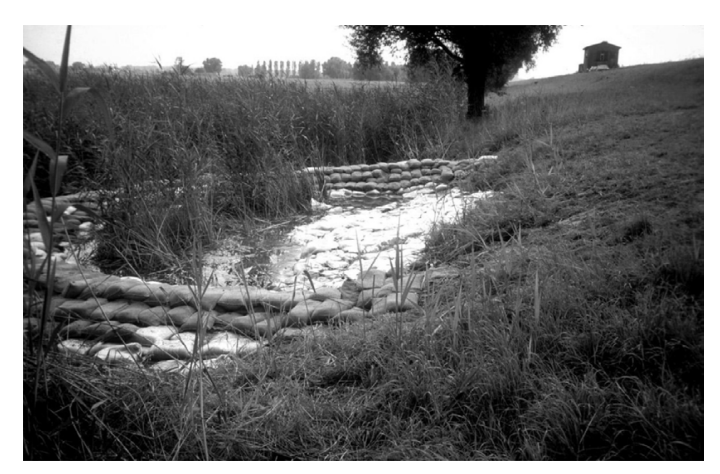

Fig. 9: "Boil ring" at dike toe. 


\section{Autorenfassung}

Heibaum: Geosynthetics for waterways and flood protection structures - Controlling the interaction of water and soil, 2014

actuating forces by improving drainage. It should be aimed at interrupting the surface runoff as early as possible, preferably above the slide prone area. Here also geosynthetic elements other than drains can be used that will be discussed in the context of mitigation the surface erosion. Additionally, ground fissures at the head of landslides should be closed by grading or ploughing to minimize the direct entry of surfacewater into the landslide - a measure that is generally recommended to reduce the surface rain water runoff. As additional measures, subsurface drains are proposed, namely trench drains, sub-horizontal drains and galleries and vertical drains. Even when the soil is not yet saturated, a water infiltration induced landslide may occur (Buscarnera and di Prisco, 2013).

Shirley and Francis (1977) give practical suggestions for installing surface and subsurface drains. Trench drains (near surface interceptor drains) are built in the manner described for dikes. Inclined (or nearly horizontal) drains have to be built in such a way that they intersect drainable strata and that clogging of drain pipes is ruled out. This can be achieved by wick drains, mostly named "prefabricated vertical drains" (PVD), but in this case installed in an inclined manner. Santi and Elifrits (2001) show in an extensive study that one of the most effective options to stabilize landslides is to reduce the amount of water by installation of horizontal drains. A bit surprisingly they propose (in 2001!) “a new type of horizontal drain material, geosynthetic wick drains" even though PVD are well-known quite some time. The authors also propose to use "a new installation method of driving drains rather than drilling". Their summarizing statement is: "horizontal wick drains offer several advantages over conventional horizontal drains: they resist clogging, they are inexpensive, they may be deformed without rupture, and they may be installed by unskilled labourers with a minimal investment in equipment". Nevertheless, installing wick drains should be planned carefully and supervised in detail to achieve an optimal solution.

\subsection{Foundations of dikes}

Dikes are built near to the sea or the river, where often soft soil is found due to the geological processes at the coast or in a valley. Soft soil leads to significant settlement due to consolidation and creep if an embankment is built. On the other hand, flood protection should be effectuated as fast as possible and the crest of a dike should not be lowered with time due to soil deformation. Therefore measures are to be undertaken to accelerate consolidation to reach the final geometry as soon as possible and/or other measures to improve the foundation.

Prefabricated vertical drains are meanwhile a standard solution to accelerate consolidation of soft soil. Design formulae for the time dependent consolidation using wick drains have been published already in 1948 by Kjellmann, which were modified by Hansbo (1976). The latter is the mostly used design approach and has been extended by Abuel-Naga et al. (2012) to take into account the effects of smear and transition zones. The efficiency of wick drains can be improved not only by preloading to accelerate the rate of consolidation but also very effectively by vacuum and/or heat preloading (Artidteang et al., 2011).

Drainage and load bearing capacity at the same time is provided by Geotextile Encased Sand Columns (GEC). These elements were developed as a load bearing system for the foundation of em- 


\section{Autorenfassung}

Heibaum: Geosynthetics for waterways and flood protection structures - Controlling the interaction of water and soil, 2014

bankments in soft and very soft soils as an alternative to conventional piles or columns of any kind (Raithel et al., 2005). It can be used in very soft soil where traditional compacted stone columns are lacking sufficient lateral support and allow transport of fine particles in the stone column, resulting in destabilization around the column. The high-strength geotextile encasement of the GEC provides the necessary radial confining reinforcement and filter function. GEC are discussed further in Section 7.2.

\subsection{Beach drains}

At the coast, the beach in front of dunes and dikes acts often as a kind of "safety margin". The coastline is not static. The waterline continuously shifts in seaward and landward direction. Years of much sea wind and few big storms let the beach and the dunes grow, but in other years they might shrinkagain. When beach and dunes erode, the sea starts to threaten properties. So the beach has to be restored, which is done by beach renourishment, extensively applied all over the world but rather costly and has to be repeated after every storm.

So the idea came up of draining beaches. The idea is to place a drainage pipe under the sand below high tide level, which directs the pore water flow from the surface towards the drain (Coastalwiki, 2008). This inward flow will stabilize the sand or even lead to accretion. The water is conducted through the drainage pipe to a collection pit from where it is pumped back to the sea. The

\section{Heibaum: Geosynthetics for waterways and flood protection structures - Controlling the interaction of water and soil. Geotextiles and Geomembranes 42 (2014), S. 375-393.}

benefits of beach draining were discovered by accident along a beach at Hirtshals in Denmark, where a public marine aquarium obtained its filtered seawater by this method (Anthoni, 2000). The system will be most effective in areas with a low tidal range (less than $2 \mathrm{~m}$ ) with a high amenity value and low to moderate wave energy. Costs are reported to be low to moderate (Scottish Natural Heritage, 2000), with high maintenance plus running costs. The drain is a typical trench, lined with a geotextile filter, and a drain pipe embedded in coarse gravel. Since storm erosion of the beach is likely to damage the system, a heavy fill and sewing the geotextile instead of overlapping might be advantageous. Also recent research in a large model flume indicates that a large diameter of the drain is favourable (Damiani et al., 2011). The hydrodynamic phenomena resulting from the presence of drains are not yet fully understood. Research results indicate that for high energy wave conditions only a local stabilization can be achieved. Two drains generated a good beach stabilization which resulted for low energy wave conditions even in beach accretion (Ciavola et al., 2011). The great benefit of this beach restoration method is that it works while being almost completely invisible. 


\section{Autorenfassung}

Heibaum: Geosynthetics for waterways and flood protection structures - Controlling the interaction of water and soil, 2014

\subsection{Drain and filter design}

It has been shown that drains can help to control successfully the interstitial water. Realizing the importance of these elements, great care has to be taken of the drain design, especially the filter.

To design a filter, two basic criteria have to be fulfilled: The finer material has to be retained and permeability must not decrease significantly in order to avoid a build-up of higher pore water pressure. These criteria are contradictory. Therefore, any design has to be carried out within narrow margins. The approaches are usually grouped into "geometrical" and "hydraulic" criteria. Geometrical criteria define limit values for void diameters to hinder the transport of finer particles through it. Hydraulic criteria define a limit value for the hydraulic gradient at which the transport of particles begins. But in most cases, hydraulic gradients can't be specified with sufficient accuracy, so geometrical criteria are used for geosynthetic filters. Additionally, two more criteria have to be fulfilled for a successful filter design: clogging resistance and survivability.

Filter rules are numerous, and there is still a lot of discussion about the "best" approach. Palmeira and Gardoni (2000) have listed more than 20 proposals without being able to draw clear conclusions. During the last decade, some approaches have been used rather consistently. In North and South America, the recommendations of Holtz et al. (1997) are used, which are extended in CFEM (2006), and the approach of Luettich et al. (1992). In Europe several rules came into use but are under discussion and revision at the moment (Heibaum, 2014).

From granular filters we know that a certain filtration length is required to retain the finer particles. A fine grain is not stopped at the surface of the filter, which could cause blinding, but may move a certain distance inside the filter until there is a sufficient small constriction to stop this particle. This effect guarantees that there is always sufficient pore volume to allow the water to drain. In geotextile filters also the retention of particles is achieved by the constrictions, here formed by fibres instead of grains. To allow for analogous filtration, Heerten (1987) proposed for thickness $25 \cdot 0_{90}<d<50 \cdot 0_{90}$ based on the work of Wittmann (1980) who found a required filtration length of $25 \cdot d_{15}$ for granular filters. Later, Giroud (1996) established based on theoretical considerations a minimum number of ca. 25 constrictions. This demand of a certain minimum thickness depends on the fibre diameter. These requirements support the general recommendation to choose sufficiently thick fabric, since thickness does not only contribute to well performing of the filter but also provides general robustness.

The above-mentioned filter rules are predominantly developed for drains and other applications with unidirectional flow. Filters in coastal and riverine training and protection structures, as will be treated in the following sections, experience often much heavier loads with high gradients and turbulent and reversing flow. Therefore tests are recommended to prove the filtration capability of geotextile fabric in such cases. BAW developed a special test with turbulent and pulsating flow to check the filtration capacity (RPG, 1994), which has recently become the European standard EN ISO 10772 (Fig. 10). In this test it has to be proven that the amount of soil washed through the geotextile is limited and decreases with time. After this test it is checked if the permeability of the particle laden fabric didn't decrease significantly by the entrapped soil particles. 


\section{Autorenfassung}

Heibaum: Geosynthetics for waterways and flood protection structures - Controlling the interaction of water and soil, 2014

\section{Direct the surface water}

To mitigate detrimental effects of flowingwater, it is desirable to affect thewater course. This is related to rainwater runoff as well as to river flow or coastal currents and waves. The major aim is always to prevent erosion completely or at least to limit the extent of erosion. If erosion can't be avoided, care should be taken that the sediment-laden water does not cause pollution of the environment.

\subsection{Storm water runoff}

Generally, it is desirable to avoid rainfall induced erosion at all. Possible protection methods are discussed in Section 7. If eroded soil becomes suspended matter in a water runoff, provisions shall be undertaken to allow for controlled sedimentation. Uncontrolled sedimentation can clog streams, storm drains, and culverts. Rain eroded soil silting up a river can become a significant impact on

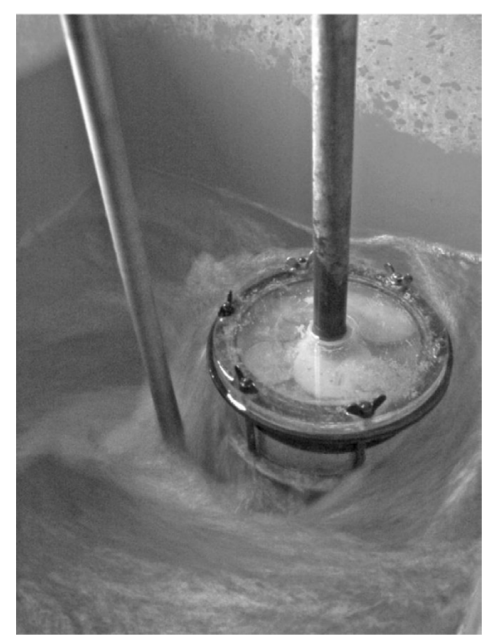

Fig. 10: $\quad$ BAW turbulence test.

Heibaum: Geosynthetics for waterways and flood protection structures Controlling the interaction of water and soil. Geotextiles and Geomembranes 42 (2014), S. 375-393.

waterways. Fluvial habitat is endangered, shipping is constrained and costly dredging becomes necessary. Intensified sedimentation can lead to increased flood heights, as sediment raises the level of the riverbed as it settles. Mitigation can be achieved by reducing the runoff velocity, dividing the runoff into smaller quantities, allowing for water infiltration and providing mechanical or structural retention methods. Such measures should be applied as near as possible to the origin of the runoff, since small rill erosion will shortly alter to gully and channel erosion, which can lead to severe decrease of functionality of earth structures. All kinds of checks, including silt fences, can be 


\section{Autorenfassung}

Heibaum: Geosynthetics for waterways and flood protection structures - Controlling the interaction of water and soil, 2014

used to achieve reduction of flow velocity and deposition of sediments. Further control measures are drains and sediments traps. Geosynthetic elements for these purposes are listed in Table 1.

\subsection{Water course siltation}

Silt curtains or silt barriers, also named turbidity barriers or turbidity curtains, are floating flexible sediment control barriers designed to prevent the spread of silt and sediment inwater bodies when work is being performed in water, on or near the shoreline, or when sediment-laden storm water is fed into a water course.

The curtains are constructed of permeable or non-permeable geosynthetic material. The curtain is suspended vertically in the water with flotation material enclosed in the top pocket and a ballast chain enclosed in the lower pocket. It can be heavily weighted at the bottom to ensure that sediment does not travel under the curtain, or a certain distance to the bottom is left to allow for water flow but to force the sediment down near the bottom.

\subsection{River training structures}

To control the course of a river, longitudinal dikes and groins are installed (Fig. 11). Such structures have to be resistant against high flow forces, requiring strong material like riprap or concrete elements. But these structures need also a stable foundation. Being placed rather often on the subsoil with much finer grains, winnowing will occur soon due to erosion of the soil through the large voids of these elements, amplified by local fluidization of the fine grained base material. Therefore a filter is an important structural part to contribute to a long lasting training structure. Filter design has been discussed in the previous section. For river training structures additional requirements hold like robustness and placement feasibility. These are equal to the requirements for surface protection measures and will be discussed in Section 8.

Besides the necessity of a filter below the groin or the longitudinal dike, geosynthetic elements offer profitable solutions for such structures. In many places in the world, gravel for the core and rock as armour is not or only limited available and concrete (for armour elements) is too expensive. In such cases, geotextile bags or containers offer a perfect solution: local fill material is filled in geosynthetic containments to build the core of the river training structures. The geotextile has to be designed as a filter towards the fill; and in most cases this means also a filter for the subsoil where 


\section{Autorenfassung}

Heibaum: Geosynthetics for waterways and flood protection structures - Controlling the interaction of water and soil, 2014

\begin{tabular}{|l|l|}
\hline Control measure & Geosynthetic contribution \\
\hline Slope drain & Geotextile filter \\
\hline Bale check & Confinement (netting) of bales \\
\hline Geotextile triangular dike & Urethane foam elements in woven geotextile \\
\hline Silt fence & Geotextile fabric \\
\hline Sandbag barrier & Geosynthetic bag material \\
\hline Rock ditch checks & Geotextile filter below rock \\
\hline Sediment trap & Geosynthetic bag material \\
\hline
\end{tabular}

Table 1: $\quad$ Runoff control measures incorporatinggeotextiles.

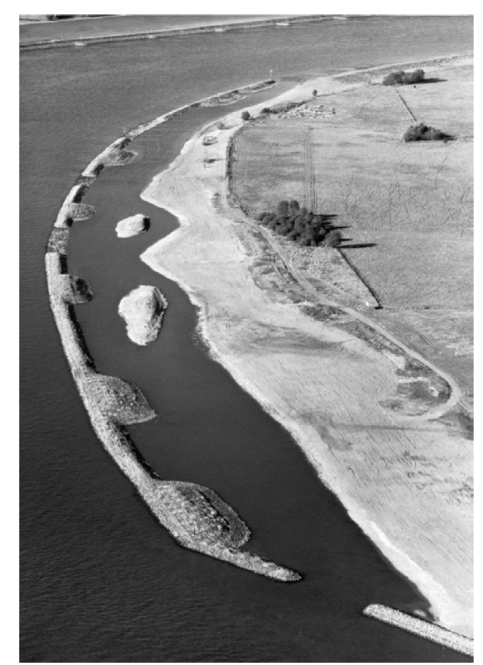

Fig. 11: Longitudinal dike with vegetated gabions.

the training structure is built upon. The structures may get an armour layer of gabions or armour stones if necessary. Using cheap local material for the major volume of the structure will result in lower costs with the same benefit.

Geosynthetic containments can also be used, to create vegetated groins and longitudinal dikes. Pilot installations have been madein the Rhine River, Germany. Rope gabions filled with rock for weight and lava for moisture storage have been pre-planted (1 year). To protect the finer grading of the lava chippings and the young roots a jute nonwoven was used to wrap rock and chippings inside 


\section{Autorenfassung}

Heibaum: Geosynthetics for waterways and flood protection structures - Controlling the interaction of water and soil, 2014

the rope confinement (Fig. 12). Unfortunately the natural fibres degraded before the roots were sufficiently developed to hold the lava chippings in place. The chippings vanished and the plants withered

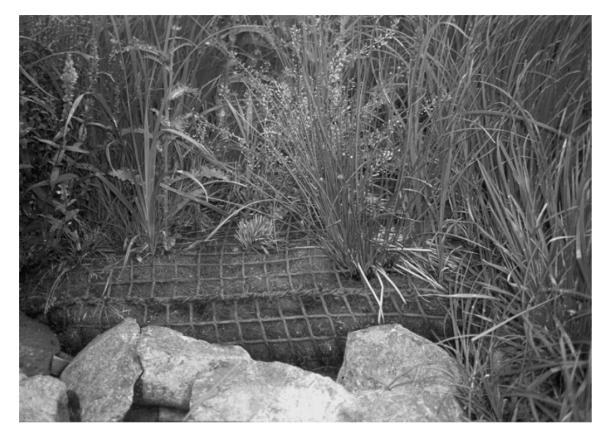

Fig. 12: Pre-planted rope gabion.

Heibaum: Geosynthetics for waterways and flood protection structures Controlling the interaction of water and soil. Geotextiles and Geomembranes 42 (2014), S. 375-393.

during the low water period. This failure teaches to choose also a synthetic nonwoven to retain the smaller particles. Nonwovens will be penetrated by roots easily and would not object the plant's growth.

\subsection{Coastal training structures}

In general, the same kind of structures as in rivers can be built at the coast to control the coastal currents. But in several applications in Australia it could be shown that it is possible to build trainings structures without armour, if the right material is chosen (Hornsey et al., 2009). For such structures 1-2.5 $\mathrm{m}^{3}$ geotextile containers are used, according to the requirements to withstand the hydraulic effects. The surface is equipped with an additional nonwoven protection layer to keep UV radiation off the original container fabric.

The same ideas as for groins and longitudinal dikes, but at a larger size, can be discussed for sea groins, jetties, perched beach, elevated or submerged breakwaters. These structures protect the coast from hydraulic effects by guiding the currents and dissipating the energy of waves hitting the coast. As for inland hydraulic structures, geotextiles are used for basal filter, reinforcement and containers for the core. Beside that exposed solutions have been built in an increasing number. PIANC (2011) lists several examples of groins and breakwaters, including artificial reefs. Reef breakwaters are coast-parallel, long or short submerged structures built with the objective of reducing the wave action on the beach by forcing wave breaking over the reef. Reefbreakwaters are normal- 


\section{Autorenfassung}

Heibaum: Geosynthetics for waterways and flood protection structures - Controlling the interaction of water and soil, 2014

ly rubble-mound structures constructed as a homogeneous pile of stone or concrete armour units, but increasingly geosynthetic solutions are chosen. One of the first applications of geotextile fabric in wetlands restoration was in the early 1970s in Galveston Bay the construction of ca. $240 \mathrm{~m}$ of geotextile tube breakwater on Galveston Island's north shoreline (GBF, 2007). One of the wellknown projects is the artificial reef at the Gold Coast of Australia. For this project numerous 200-500 $\mathrm{m}^{3}$ containers are used (Hornsey et al., 2002). After some time, an additional benefit was observed: coastal habitat developed very quickly on and in between the containers (Corbett et al., 2010).

\section{Strengthen the structure and the ground}

\subsection{Reinforcement}

If the water flow cannot be modified, structures and ground have to be strengthened to be able to withstand unfavourable actions of the water. One can easily imagine that structures like a large embankment of a navigation canal or any dike need a maximum of safety. Already our ancestors used reinforcement for hydraulic structures like embankments, dikes or seawalls, mostly made from steel or concrete - in the early days wood was used - but today geosynthetic solutions have proven to perform very well due to their strength and their flexibility. Basal reinforcement of dikes and embankments is used against lateral spreading. Slope reinforcement increases the overall stability and allows for steeper slopes. Reinforcement is mostly done with woven fabric or extruded grids, but also nonwoven fabric as used in wrapped wall structures (as described in the next section) or staple or continuous fibres mixed into the soil provide strength (Khay et al., 1990) and improve earthquake resistance (Fukuoka et al., 1990). Fibre-reinforcement also protects the soil from erosion to a certain extent because the fibres form a protecting cover after the top soil particles are washed away. Since the installation procedure needs some effort, such measures have been worked out only in a few cases.

Reinforcement by grids alone always has to be sided by erosion protection measures, if there is an interaction of water and soil to be expected. Internal erosion as well as surface erosion or scouring can't be avoided by reinforcement alone, because the grids are much coarser then the soil particles. Furthermore the flood water table has to be taken in consideration when designing a reinforced structure because the stress state changes due to buoyant forces when a significant part of the ground is ponded and also all apparent cohesion is lost when the soil is fully saturated. To neglect erosion and buoyancy may cause severe damage (Gruber, 2008).

An often heard answer to the question, what can be done to protect housing or communities against flood is to increase building resilience. This can be achieved by elevating homes and public buildings above (at least a frequently reached) flood level (Section 4.1) and to use water-resistant building materials such as concrete or ceramic. Unfortunately in many countries or small islands, it would be rather costly to import cement and aggregates becausenatural resources are far away. So the plinths of the houses are built of erosion-prone material. Geotextile containers can provide sta- 


\section{Autorenfassung}

Heibaum: Geosynthetics for waterways and flood protection structures - Controlling the interaction of water and soil, 2014

bility for plinths. By this method, reinforcement of the foundation as well as an increase in strength of the water-loaded surface is achieved.

\subsection{Geotextile encased columns (GEC)}

Building dikes and embankments on soft soil is always a challenge since extensive settlement is to be expected due to consolidation and creep. Prefabricated vertical drains (PVD) as addressed in Section 5.3 help to accelerate the settlement but do not reduce it and will not affect creep settlement. To achieve sufficient bearing capacity when a longer consolidation time cannot be accepted, additional measures are needed.

Often compacted gravel columns are used for foundations in soft soils, but such techniques are usually limited to soft soils with undrained shear strength $c_{u} \geq 15 \mathrm{kN} / \mathrm{m}^{2}$. With lower strength, the lateral support of the column material would be too low. This problem was solved by geotextile encased columns (GEC), i.e. compacted sand or gravel confined in a geosynthetic encasement. An appropriate technology, design procedures and adequate geosynthetics were developed throughout the 1990s. To withstand the high ring tension forces, the woven geotextile casings are manufactured seamlessly. The first projects started successfully in Germany around 1995. Since then projects have been completed in several countries. The design procedure was developed by Raithel (1999). Today also systems using geogrids for strength and nonwovens for filter/separation are applied (Lee et al., 2008; Wehr and Heerten, 2005).

GEC transfer the load through the soft soil down to a firm stratum while high-strength geosynthetic reinforcement is typically installed horizontally above the piles to bridge over the soft soil in between. The vertical compressive behaviour of the GECs is less rigid than that of steel or concrete piles. The compacted sand or gravel columns undergo compression under load mainly due to radial outward deformation of the encasing. The geosynthetic encasement provides a confining radial inward resistance. The mobilization of ring forces requires some radial extension of the encasement (usually in the range of 1-4\% strain) in the ring resulting consequently in vertical settlement of their top. The GEC system therefore cannot be completely settlement-free but most of the settlement occurs during the construction stage - there is no delay due to consolidation.

The specific characteristics of the GEC system are (quoted from Alexiew et al., 2012):

- The primary function of the high-modular high-strength geotextile encasement is the radial confining reinforcement of the bearing (sand or gravel) column. 


\section{Autorenfassung}

Heibaum: Geosynthetics for waterways and flood protection structures - Controlling the interaction of water and soil, 2014

Heibaum: Geosynthetics for waterways and flood protection structures -

Controlling the interaction of water and soil. Geotextiles and Geomembranes 42 (2014), S. 375-393.

- The secondary functions of the encasement are separation, filtration and drainage.

- The system is not completely settlement-free.

- The GEC is typically an end-bearing element transferring the loads to a firm und erlying stratum.

- The GECs are-water-permeable; they practically do not influence the groundwater flow, which has potential ecological advantages.

- The GECs may also perform as high-capacity vertical drains.

GEC are installed by two installation methods. Either by the vibro displacement method, where a steel pipe with two base flaps is vibrated down to the bearing layer, displacing the soil, or by the excavation method, where an open steel pipe is driven down and its contents is removed by auger boring. The first is being used in soft soils, the second in less soft soils or when vibrating is prone to cause damage. Then the geotextile casing is installed in the pipe and filled with sand. The pipe is pulled out under vibration which causes compaction of the fill. One of the first dike foundations was realized for an area extension of an airplane dockyard in Hamburg, Germany, by about 60,000 geotextile encased columns with a diameter of $80 \mathrm{~cm}$, which extended 4-14 m below the base of the dike footing (Raithel and Kirchner, 2008).

\section{Protect the surface against hydraulic impact}

\subsection{General}

From soft rain to heavy wave impact: soil particles are always prone to being transported by the water resulting in ground instabilities. To what extent this will happen is always a question of intensity, duration, ground quality and geometrical boundary conditions. In this context, "surface erosion" is defined as water-generated erosion due to occasional water load, while "scour" indicates the removal of submersed material by waves and currents.

The confining structures of waterways and reservoirs (bed, bank, embankment) and flood protection structures like dikes, seawalls etc. in most cases are built according to national and local regulations, including an individually required safety margin. To keep this safety, any alteration of the structure must be prevented. That includes that no erosion or scour can be tolerated because it would weaken the structure. Therefore relevant protection is needed on the face as well as at the toe to hinder surface erosion and regressing failure due to scour and erosion. 


\section{Autorenfassung}

Heibaum: Geosynthetics for waterways and flood protection structures - Controlling the interaction of water and soil, 2014

\subsection{Rainfall erosion}

Rainfall erosion is a problem predominantly when bare soil is exposed, e.g. during and after construction processes. Often a construction process also disturbs the ground, which then will be even more vulnerable to being washed downhill. Erosion can start with the impact of raindrops. Raindrop impact dislodges soil, causing it to be splashed into the air (therefore called "splash erosion"). The splash effect also increases compaction and destroys open soils structure, which is - at least in the beginning - not relevant for safety considerations but for agricultural use. The next step is transportation of soil loosened by raindrop splash, resulting in sheet erosion. This is a removal of soil from sloping land in thin layers, depending on soil type, depth and flow velocity. The increase of runoff may cause rill erosion. This type of erosion occurs where sheetflow becomes concentrated in small, defined channels that are a few centimetres deep, but growing deeper and forming gullies. This process is accelerated enormously when the soil is highly saturated due to intense rainfall and therefore unable to absorb any more water. When the flow velocity is further increased or if the flow is concentrated due to the local damage of vegetation, channel erosion occurs that may lead to damage of an earth structure.

Countermeasures against rainfall induced runoff of sediment-laden water in rills or gullies have been discussed in Section 6. But the best countermeasure would be to hinder the initiation of erosion at all. Such measures are actions that are often taken on an interim basis pre, during, and post construction to minimize the effects mentioned above. Geosynthetics can be used in many aspects.

Mulching is often proposed to shelter the bare soil surface to avoid erosion und to support vegetation growth. To protect the light mulch material against dislocation and wind erosion, synthetic grids of thin threads might be sufficient (Fig. 13). Like mulch, erosion countermeasures are often needed only temporarily, so for many applications natural fibres can be used. Such fibres will disintegrate after a certain time, but may remain strong enough until the final situation regarding geometry, vegetation or other is reached.

If planting or reseeding on slopes is not successful due to the local boundary conditions, erosion protection mats may help to reduce the impact on the bare or newly vegetated soil. With such a protection, roots are able to establish themselves and stabilize the soil. Due to steepness or wind impact, an erosion protection sheet might need to be fixed to the ground, commonly by means of pins (usually on a $1 \times 1 \mathrm{~m}$ grid) to ensure proper contact of mat and ground. If pinning is not possible, the fabric has to be anchored in ditches at the top of the slope. For such applications, products have to be used that provide the tensile strength needed. For reliable seeding, erosion protection mats can be filled with seed, if necessary combined with soil or stone chippings within the fabric. To resist strong impact, a bitumen-bonded filter fill of the mat in combination with (hydro) seeding can provide the desired outcome. 


\section{Autorenfassung}

Heibaum: Geosynthetics for waterways and flood protection structures - Controlling the interaction of water and soil, 2014

\subsection{Overtopping}

Dikes are not necessarily designed to hold back every conceivable flood, and they might not perform perfectly even when they are faced with routine floods, e.g. when unexpected settlement occurs or debris blocks spillways. On the other hand, flood risks are assumed to increase because of more intense rainfall, stronger wind speeds and increases sea levels. Therefore, it might be advantageous to design the dike or levee for possible overtopping.

Overtopping of an earth structure like a dike or embankment can create erosion damage on the crest and the rear face if the discharge exceeds $1-10 \mathrm{l} / \mathrm{s} / \mathrm{m}$ and the surface is covered by grass, but only $0.1 \mathrm{l} / \mathrm{s} / \mathrm{m}$ if there is no protection of the surface (EurOTop,

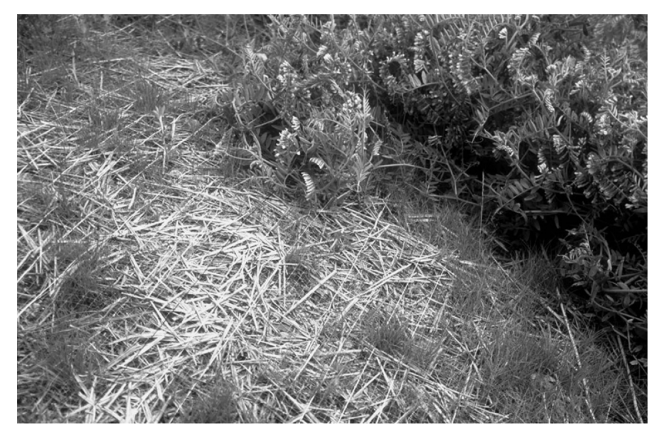

Fig. 13: Mulch secured with thin geogrid.

Heibaum: Geosynthetics for waterways and flood protection structures Controlling the interaction of water and soil. Geotextiles and Geomembranes 42 (2014), S. 375-393.

2007). Overtopping can also create slip failure which will lead to a breach even faster than erosion. Such slip failures occur mainly for slopes steeper than 1:3, so nowadays most dikes are built with a landward slope of $1: 3$ or flatter.

A flood event in a river does not necessarily mean that the whole course of the river is threatened equally. The severe floods of the river Mississippi in 2008 showed that while a 1000-year flood took place at one place, only a 13-year flood occurred approximately $225 \mathrm{~km}$ downstream (Bernhardt et al., 2011). Overtopping often sides with saturation of the dike, which weakens the structure generally and which makes it easier for the overtopped water to cut into the slope surface or into the toe of the dike, regressing to the crest unless creating a breach. The degree of such a process is dependent on the depth and duration of the overtopping as well as the soil properties. The impact of overtopping can be mitigated in some places by a rising water level on the downstream side. At that time flow perpendicular to the levee is reduced while flow along the embankment continues. The 


\section{Autorenfassung}

Heibaum: Geosynthetics for waterways and flood protection structures - Controlling the interaction of water and soil, 2014

velocity of the flow in the direction of the main axis of the river is usually much lower than the velocity of the overtopping flow perpendicular to the main axis that can reach $10 \mathrm{~m} / \mathrm{s}$.

The primary shelter of dikes and embankments againsthydraulic loads is the grass cover. But to act successfully, a dense cover with well-developed sod is required. Bernhardt et al. (2011) report that in damaged areas after the Mississippi flood most of the grasses present were annual weeds rather than sod forming grasses. Such weeds are only present for a portion of the year and tend to clump leaving spaces where the soil surface is bare. In springtime such weed can be very invasive and can take over an area, but because it is an annual plant it will die out during a freeze. Therefore such cover cannot be considered as a protective armoring. In other places some types of grass survived the continuous flow of water and had a positive impact on preventing erosion. Additionally the flow forces laid the grass down, creating a protective cover on top of the soil surface.

Temple et al. (1987) discuss the possible erosion mechanism in grass-lined channels. It is observed that soil particle detachmentcan begin at low stresses that do not affect vegetation. But as the soil particles are removed, the vegetation is undercut and the weaker vegetation is removed. This way the density and uniformity of the cover is decreasing with the result of an increased erosion rate. A conforming observation was made during the overtopping tests in the ComCoast project ("Combined functions in the coastal zone" - European Interreg IIIB project 2002-2007 with partners in The Netherlands, Denmark, Germany, Belgium and the United Kingdom). These tests showed that if there is one hole in the grass surface, more erosion will follow in a zipper effect. So roots alone provide not sufficient shelter against erosion. In the ComCoast tests, the grass cover was stable until a discharge of $30 \mathrm{l} / \mathrm{s} / \mathrm{m}$ or even $50 \mathrm{l} / \mathrm{s} / \mathrm{m}$ (Van der Meer, 2008). But it has to be pointed out that the ground was unsaturated. After a long flood period, the dike body would be saturated which increases the vulnerability significantly. Furthermore it was realized that transitions from crest to slope are most susceptible to damage.

Since the resistance of vegetation against erosion is mainly due to the sod, the aim of the cover is not to allow soil particles to pass and not to allow for bare spots in the vegetated area. This is provided in many cases by stone revetments or a layer of open asphalt. Such layers are often covered with soil, allowing grass to grow on it so as to make the dike look 'green' again. A much more elegant solution can be provided by geosynthetic systems.

There are several methods to introduce geosynthetics to the flow resisting system. Threedimensional erosion protection mats can be used like discussed above as countermeasure against rainfall erosion. Within the ComCoast project a grass reinforcement system (Smart Grass Reinforcement, abbreviated SGR) has been developed and tested (Van Gerven and Akkerman, 2006). In this system a geosynthetic grid is placed a few centimetres below the surface to strengthen the grass sod. In case that the grass cover is not flawless or hydraulic impact has locally removed the grass, the geosynthetic grid bridges the bare spot. Ideally the grid is installed from the very beginning. But since often strengthening is required for an existing dike with grass cover, a method was developed to place the geotextile fabric below an existing grass cover. (Certainly it needs some time to let the lifted roots grow through the grid into the ground below.) During the field tests, the SGR proved to function very well. However, large-scale installation of the SGR awaits still some further 


\section{Autorenfassung}

Heibaum: Geosynthetics for waterways and flood protection structures - Controlling the interaction of water and soil, 2014

development when applied at existing dikes. This method reinforces the grass armour, the retention of soil particles is provided only by sufficiently closely spaced roots of the sod.

A different approach is made by Haselsteiner et al. (2008), also described in PIANC (2011). The general idea is to sacrifice a certain top layer, but to keep the dike core erosion resistant. In the case that the grass cover is not strong enough, grass and top soil would be washed away, but erosion can't go further due to geotextile elements that hinder erosion and ensure overall stability. This can be achieved by wrapping the core material, either using geosynthetic containers of a size that would be large enough to withstand hydraulic loads and impacts. Or a "wrapped around" method is chosen, where a geotextile sheet enfolds soil layers of limited thickness (depending on the boundary conditions, $0.3-1.0 \mathrm{~m}$ ).

\subsection{River and canal bank and bottom protection}

Bankstability depends on a multiplicity of influencing factors: on the one hand, multiple (hydraulic) actions act on the bank (internal flow, natural or ship induced external flow and waves), on the other hand resistance is depending on bank material (cohesive, non-cohesive, etc.), bank stratigraphy (uniform, layered), soil moisture (degree of drainage/saturation), forms of vegetation in the riparian zone and on the bank, bank and channel geometry (steepness, height, depth). In navigable channels the actions may be amplified by the rapid drawdown of water level caused by passage of vessels, by the distance of the ship to the bank or by the screw-race of the main propeller or the bow thruster (Fig. 14). These hydraulic effects may lead to scouring which in turn will affect the bank stability and thus safety on land and in the water.

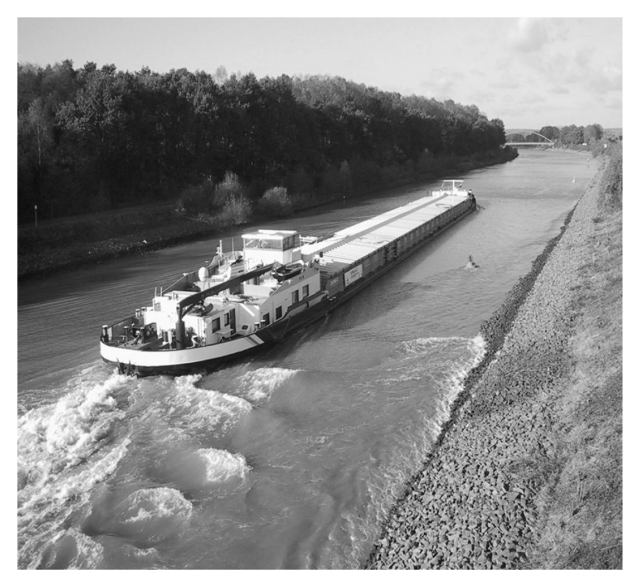

Fig. 14: Drawdown and transversal stern waves on the bank during vessel passage. 


\section{Autorenfassung}

Heibaum: Geosynthetics for waterways and flood protection structures - Controlling the interaction of water and soil, 2014

\section{Heibaum: Geosynthetics for waterways and flood protection structures - Controlling the interaction of water and soil. Geotextiles and Geomembranes 42 (2014), S. 375-393.}

A limited local scour may be tolerated, but as soon as scour increases with time, countermeasures are needed. Only if natural adjustment can be tolerated, no intervention is necessary. Otherwise either the action has to be reduced or the resistance has to be increased. Changing the action means to alter the flow, e.g. by appropriate rules for navigation or by river training works (Section 6). Often increasing the resistance might be the better way regarding costs, resilience and sustainability.

Increasing the resistancemeans at first to strengthen the water exposed surface to hinder the hydraulic transport of material. In most cases hard armour is chosen as bank protection. In these applications, minor scouring at the borders of the protection layer is inevitable, which can be accepted to a certain extent. But from that a general demand arises: a good scour protection system has to be flexible. The demand for flexibility holds for all elements of a scour repair and prevention work, i.e. fill, filter and armour. When using rigid systems, it has to be guaranteed that neither below nor beside the armour any erosion will develop. This can hardly be achieved, so a flexible system always performs better.

A traditional structural measure is to place riprap designed to the hydraulic loads acting. For a sustainable scour protection it is essential to place a filter layer in between the coarse riprap and the often fine subsoil. Geotextile filters perform well for that purpose (PIANC,2011). If there is no filter at the interface subsoile-armour, the coarse material will sink into the subsoil due to fluidisation of the subsoil. This process will continue until so much armour material is installed that there is an equivalence ofload and resistance due to the mere thickness (that might not be sufficient for a following larger hydraulic load).

Geotextile filters below armour layers do not only provide filter stability but also scour resistance if the armour is damaged. Today's ships are equipped with bow thrusters which mean an extra load on the revetment when used near the bank. If riprap is locally displaced by the screw-race of the bow thruster, the geotextile will still protect the bank subsoil due to the membrane effect (Fig. 15). A granular filter would have been gone and with it a significant amount of fill material of the subsoil, which reduces the slope stability and can have dramatic consequences in embankment dams.

Scour protection measures often have to be built in flowing water or under wave action. To place geotextile filters in such an environment, special equipment is needed. Usually the geosynthetic sheets are sewn together to achieve as few overlaps as possible. Immediately after drowning the fabric, dumping of riprap is 


\section{Autorenfassung}

Heibaum: Geosynthetics for waterways and flood protection structures - Controlling the interaction of water and soil, 2014

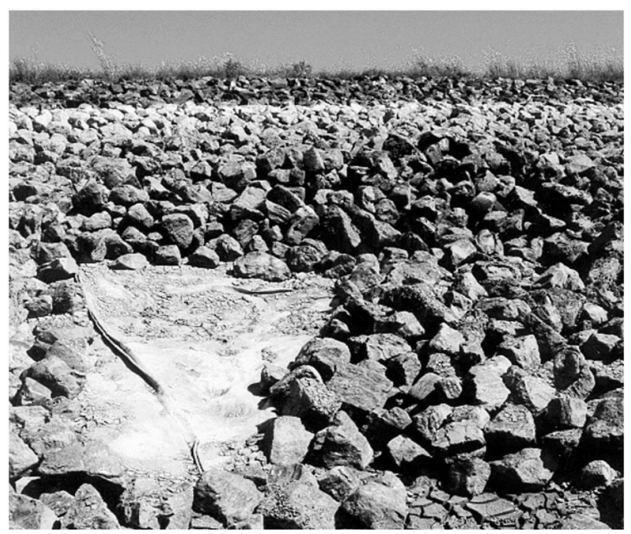

Fig. 15: Geotextile filter bridging scoured armour.

necessary to keep the filter on the ground. Without ballast, the fabric would float, not only because of the specific weight of some polymers below $1.0 \mathrm{~g} / \mathrm{cm}^{3}$ but predominantly because of the air bubbles trapped in the fabric. To keep the filter sheet in place despite air bubbles, in moderate flow or under mildwave action a "sandmat" - a sand fill in between two geosynthetic cloths - can be installed. Such sandmats have proved in tests to remain in place loaded by currents up to $0.8 \mathrm{~m} / \mathrm{s}$, depending on the flow pattern. The maximum fill available today is ca. $9 \mathrm{~kg} / \mathrm{m}^{2}$ since with more sand fill the needles for sewing or needle punching will degrade too fast.

With strong current acting, geosynthetic cloth cannot be placed properly, but a granular filter would be eroded as well. Armour elements like riprap would be stable against the current, but would not provide the filter stability necessary to prevent erosion of the subsoil. A combined armour and filter system is given by certain mattresses, e.g. concrete blocks cast on a woven geotextile. Such block mattresses usually are assembled in the dry and placed by special cranes. Such systems need high effort and are consequently rather expensive. Also the weight of the blocks is limited.

To overcome filter placement problems, elements are needed that combine filtercapacity and sufficient weight to withstand the hydraulic action. The protection system also should be able to adapt to any subsoil geometry (including existing scour holes) and it should be flexible to follow further scouring, e.g. at the edges of the scour protection. For such purpose, geosynthetic bags and containers are used successfully. The container fabric has to be designed as a filter towards the subsoil and the fill. To prove the capability, large size model test were performed in a flume of Colorado State University (Lagasse et al., 2007). For additional safety, granular filter material can be used as fill. Contained in geosynthetic fabric, placement of granular filter material will be successful, since the containment hinders segregation.

Even though bags and containers can resist the loads acting on a bank protection, in most cases an armour layer is added. Actually they mightbe left without armour if hydraulic stability is provided. Pilarczyk (2000) reports that tests proved stability of bags of $30 \mathrm{~L}(45 \mathrm{~kg})$ when loaded with a current of $2 \mathrm{~m} / \mathrm{s}$. In Bangladesh an attempt was started to use geotextile bags alone filled with fine 


\section{Autorenfassung}

Heibaum: Geosynthetics for waterways and flood protection structures - Controlling the interaction of water and soil, 2014

river sand for bank protection because of the shortages of local aggregate for concrete and no suitable rock for riprap (Oberhagemann and Sharif-Al-Kamal, 2004). But resources as sand and labour were sufficiently available. Rivers in Bangladesh are characterized by great instability, including deep scouring, very high discharges, exceeding 150,000 $\mathrm{m}^{3} / \mathrm{s}$ during the 100 year flood and high flow velocities in excess of $4 \mathrm{~m} / \mathrm{s}$ at exposed places. Based on ample testing, a "geotextile bag revetment" has been chosen for riverbank protection using bags of relatively small size $125 \mathrm{~kg}$ - so one (!) man can carry it) as permanent protection against riverbank erosion without armour. After two high flood seasons no failures were observed and the work performs well (Fig. 16). Details of testing and design are given by Heibaum et al. (2008).

Banks of rivers and canals are often significantly steeper than it would be the consequence of natural development. Therefore bank protection is necessary, usually provided by hard armour. Increasingly effort is put into bioengineering solutions, i.e. the integration of vegetation. Vegetative elements can be used in areas that are only temporarily drowned or loaded by hydraulic actions. Often grass is used to provide a certain erosion protection. For stronger resistance pre-planted gabion-like structures are used with success. An example is the use of elements, where the core is made of heavy stones to guarantee stability in combination with lava material to keep sufficient moisture during dry periods. To protect the (small) lava particles and the small plants from being washed away, a filter is wrapped around the unit and the strength is achieved by a confinement of a geosynthetic mesh (Section 6.3). Very strong

Heibaum: Geosynthetics for waterways and flood protection structures Controlling the interaction of water and soil.

Geotextiles and Geomembranes 42 (2014), S. 375-393.

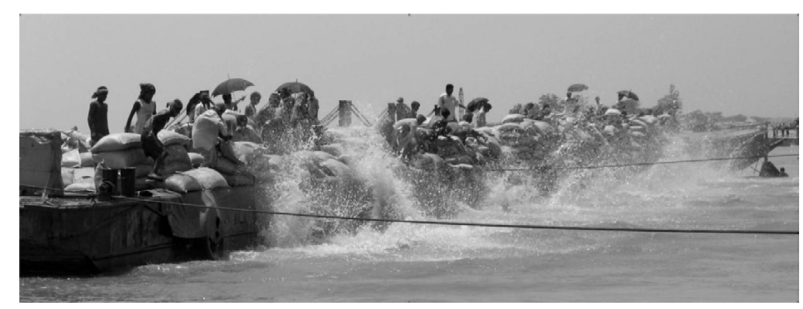

Fig. 16: Installation of bag revetment (C) Oberhagemann).

protection can be build combining stacked gabions (includinga well-designed filter), containers or tubes with plants in between, predominantly willows (brush layering). The geosynthetic elements provide erosion protection of the subsoil while the plants act as "ground anchors" of the whole system. Additionally they grant the protection of the geosynthetic fabric against weathering. Even though "green solutions" are desirable, it is safety that has to be focused on. But a closer look at the elements of bank protection reveals certain possibilities to complement the technical solution by vegetative elements (Heibaum, 2012). Since weight is a major factor, pure biological solutions are 


\section{Autorenfassung}

Heibaum: Geosynthetics for waterways and flood protection structures - Controlling the interaction of water and soil, 2014

only possible if sufficiently deep roots activate the top soil layer for resistance against the hydraulic loads.

For scour protection and repair at highly stressed areas, a traditional countermeasure is to place fascines to provide a sufficient resistance against the current. Originally large willow bundles that have a core of rubble or riprap are used. Today, instead of these elements often geosynthetic containers are installed (Heibaum, 2004). Being exposed to high hydraulic and mechanical loads, the container material with sufficient strength has to be chosen. Usually there is a choice of wovens and nonwovens. The first have the advantage of high tensile strength, the second the advantage of large straining capacity. If the casing material is damaged, a woven cloth might be more susceptible to the zipper effect than a nonwoven. Nonwoven fabric usually has a high straining capacity. By allowing large deformations it will be able to withstand the impact load when hitting the ground after being dropped into the water as well as when the stones are dumped upon. For waterways, a minimum mass per unit area of $500 \mathrm{~g} / \mathrm{m}^{2}$ and a minimum tensile strength of $25 \mathrm{kN} / \mathrm{m}$ are recommended and the strain at rupture should be larger than $50 \%$. Since the container has to sustain abrasive forces e.g. due to bedload transport, any geosynthetic material used for containers needs high resistance against abrasion. This can be tested in special rotating drum test (RPG,1994). Experience shows that fabric that survived the test performed well for very long time.

Local protection around bridge piers or dolphins can be perfectly done by geosynthetic containers. Already in 1997 geotextile containers of $1 \mathrm{~m}^{3}$ volume were used for scour protection at bridge piers and dolphins in an estuary in Germany (Smoltzczyk, 2003). Placement was successfully done in spite of the maximum flow velocity of $2 \mathrm{~m} / \mathrm{s}$ and no damage is reported to date.

\subsection{Coastal surface protection}

Also at the coast, protection is sought either by reducing the actions or increasing the resistance. Reducing the action can be done by coastal training structures or offshore barriers like breakwaters and artificial reefs, groins and jetties. Geosynthetics incorporated in such structures have been discussed above. To increase the resistance of the coastline, a number of structures and elements are available, in which geotextiles can play a major role (PIANC, 2011):

- Revetments with the principal function of protecting the shoreline from erosion have to include a filter except impervious solutions (but with these often a separation layer is used). Revetments are installed for bank, beach and dune protection. They can be covered by beach sand and are exposed only after severe storm surges.

- Seawalls are built parallel to the shoreline to stabilize the coastal profile. Seawalls range from vertical structures, such as gravity concrete walls, steel or concrete piling and similar structures to sloping structures with surfaces of various armour materials.

- Perched beach structures are hybrid solutions, being submerged and shore-parallel, often located within the surf zone.

For such structures, comparison should be made as to costs, construction feasibility, durability, etc. between standard solutions or geosynthetic alternatives. 


\section{Autorenfassung}

Heibaum: Geosynthetics for waterways and flood protection structures - Controlling the interaction of water and soil, 2014

Above and below water protection is needed for natural and artificial waterfront structures, e.g. erosion protection around groins on the foreshore, dune or dike protection. Coastal revetments are often built on a fascine mattress. This is an old but still the only method to install a filter under water at the coast. The oldest form of such a mattress is willow bundles with a diameter of $10 \mathrm{e} 40 \mathrm{~cm}$ fixed crosswise to form a large grid combined with a continuous layer of brushwood. But brushwood alone is an insufficient filter. Erosion may be slowed down due to the damping of the erosive effect of the current, but it will not be stopped. The important step forward was made when combining fascines and geotextiles to a fascine mattress (also called willow mattress). Modern fascine mattresses usually comprise a base woven geotextile with willow bundles tied on it (Fig. 17). The fascines ensure the spreading of the geotextile and the floating of the mattress during the transport to the area of installation. To improve the filter function, a geocomposite of nonwoven (for filtration) and woven fabric (for strength) is applied. Fascine mattresses are prefabricated according to the desired geometry on land, and then they are pulled to the desired position and drowned by dumping armour material upon. The fascine mattress and the armour designed according to the hydraulic impact form a perfect marine revetment. Placement is possible even in greater depth.

An alternative form of a revetment is a mattress filled with concrete or mortar. Such protection can be placed continuously, i.e. without overlaps that always bear a certain risk of improper covering. The base and top fabric is sewn together before the mattress is filled. When installed under water, the same problems arise as with geotextile filters: The fabric tends to float before it is filled. Mattresses of uniform thickness are inflexible and

Heibaum: Geosynthetics for waterways and flood protection structures Controlling the interaction of water and soil.

Geotextiles and Geomembranes 42 (2014), S. 375-393.

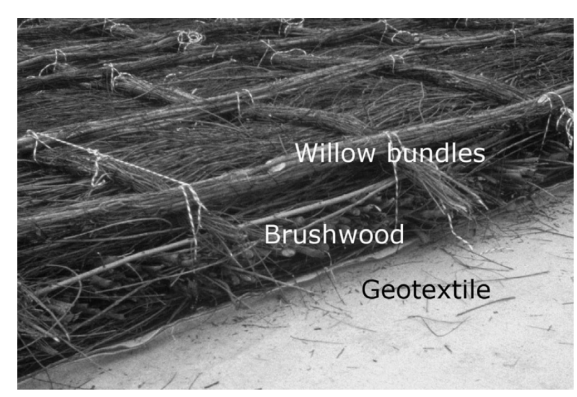

Fig. 17: $\quad$ Fascine mattress.

impermeable. To achieve a certain flexibility and permeability, mattresses consisting of columns and rows of "pillows" are used. The seams between the concrete filled pillows provide the necessary permeability of the layer (usually an extra filter fabric is needed) and the desired flexibility for good adjustment to the deformation of the subsoil. 


\section{Autorenfassung}

Heibaum: Geosynthetics for waterways and flood protection structures - Controlling the interaction of water and soil, 2014

If mattresses have to be designed for special purposes, geosynthetics allow for adequate adaptation. To install flood barriers to protect Venice from flooding, the fine seabed material of the Venice lagoon hat to protected against erosion. A layer of rockfill was installed on a ballasted filter mattress. For this mattress, a gravel filled geomat of $40 \mathrm{~mm}$ thickness was confined by filtering geotextiles on bottom, top and at the sides. Around $600,000 \mathrm{~m}^{2}$ are covered by such a revetment that is expected to perform better than traditional solutions (Scotto and Vicari, 2009).

Since the base geotextile of a fascine mattress is a woven geotextile, the limited shear resistance of the fabric may cause problems when installed on sloping sea ground. This was revealed during works to limit scour extension of maybe the largest scour at the German coast. Due to adverse flow conditions because of the closing of the most lateral gate of the Eider storm surge barrier in Germany, a scour hole as deep as $23 \mathrm{~m}$ below the sea bottom with additional $6 \mathrm{~m}$ of water depth developed (Heibaum, 1998). The inclination of the upper part of the scour slope was as steep as 1:1. Trials with fascine mattresses on even flatter slopes resulted in sliding of the mattress. With such boundary conditions, only nonwoven containers with sufficient friction resistance of the fabric could be used. So 1- $\mathrm{m}^{3}$ geocontainers were installed to build up the filter layer from the toe upwards (Fig. 18). Ca. 40,000 containers were dumped by side dumping vessels. Divers checked that the area to be protected was covered completely and no gaps remain between the containers through which the subsoil could erode. During the works, the flow velocity of the tidal currents was up to $2.5 \mathrm{~m} / \mathrm{s}$.

In the tidal zone, berms, dunes, cliffs or dikes are heavily charged - mostly temporarily during storm events - by wave run up, wave impact and possibly by strong currents. To resist storm action, a number of geosynthetic solutions can provide "reinforcement" to these structures. Geosynthetic tubes, containers or wrapped around structures have demonstrated in many cases to be able to guarantee the necessary strengthening of the coastline.

Dunes are a natural sea defense that prevents the hinterland from flooding. Consisting of sand, dunes are rather vulnerable towards hydraulic impact. Vegetation stabilizes the surface, but small scarfs in the vegetation cover can lead to severe erosion. Therefore "built-in" strengthening, provided by geosynthetic elements would be highly appreciated in many places. Geotextile bags, containers and tubes can be used as (often hidden) mass gravity construction to provide more stability. Often the first impediment for coastal waves and currents is a berm in front of the dune or the dike. Such berms are worth to be strengthened to reduce this way the impact on the structures further inland.

There are numerous ways of realization: Single or stacked tubes, stacked containers or gabions, or layers of sand wrapped in geotextile sheets have been executed with success. When using tubes, care has to be taken to attach a scour apron that is long enough to prevent from undermining in the case of local scouring in front of the tube. The length should be twice the design wave height following a rule of thumb of Eckert (1983) for scour protections. To the free end of the scour apron, usually a small sand-filled tube is attached. The main tube is rather stiff and would not be able to adjust to a local sour under the tube but would bridge it. In this regard, containers perform better because of being smaller and thus more adaptive. Because of the smaller size, vandalism is less a problem 


\section{Autorenfassung}

Heibaum: Geosynthetics for waterways and flood protection structures - Controlling the interaction of water and soil, 2014

with containers, since the amount of fill lost through a hole in the fabric is much smaller. Also placement might be done more easily - tubes can only be filled hydraulically while for containers often rather simple fill procedures are sufficient. Some structures are combinations of these elements: In India tubes

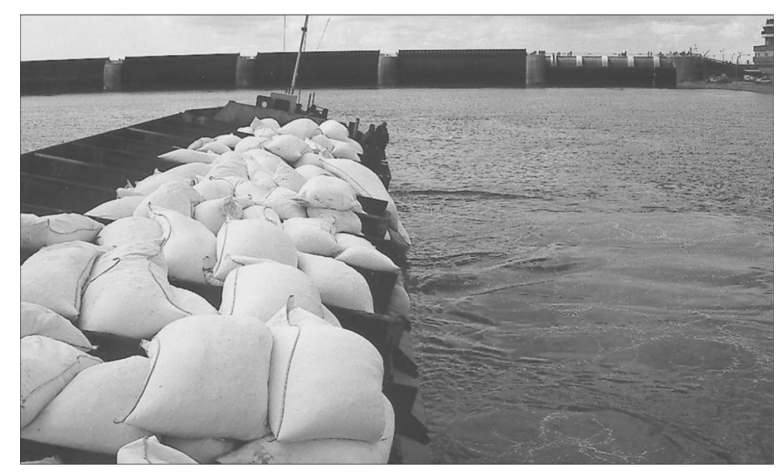

Fig. 18: Dumping geotextile containers for scour protecting filter layer.

\section{Heibaum: Geosynthetics for waterways and flood protection structures -} Controlling the interaction of water and soil. Geotextiles and Geomembranes 42 (2014), S. 375-393.

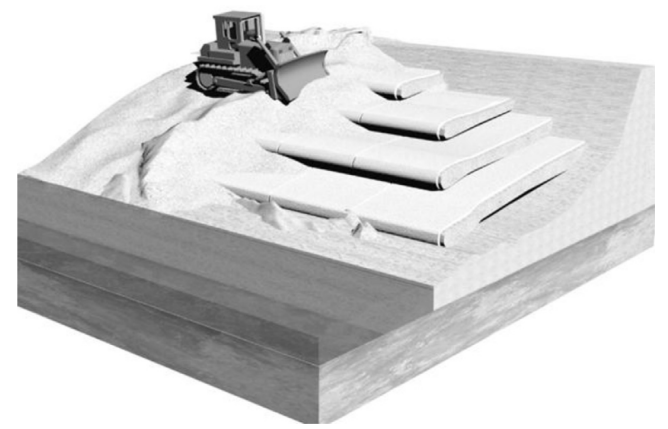

Fig. 19: Wrap-around revetment (CNaue).

covered with armour of rope gabions have been installed successfully (Venkatraman and Murugesan, 2010).

Seawalls are the most robust coastal defence structures, built often in particularly exposed situations. Even in such harsh environment geosynthetic structures like stacked tubes or containers have proven to perform well. Sadlier et al. (2010) report that even an incomplete wall survived a coastal storm with wind speed up to $140 \mathrm{~km} / \mathrm{h}$. For this structure nonwoven containers of around 4.5 tons weight and a confining nonwoven with $1000 \mathrm{~g} / \mathrm{m}^{2}$ have been installed. Matsushima et al. 


\section{Autorenfassung}

Heibaum: Geosynthetics for waterways and flood protection structures - Controlling the interaction of water and soil, 2014

(2008) performed extensive tests that revealed an increase in stability when the elements were $18^{\circ}$ inclined inward. Also good compaction and well graded fill material provide benefits.

The advantage of geosynthetic structures is their flexibility; the disadvantage may be an increased vulnerability. So the design of structures of stacked tubes or containers with or without other surrounding or covering material from rock to sand has to cover numerous details. The hydraulic boundary conditions have to be determined, like current, wave intensity, overtopping, but also groundwater or seepage water flow. The configuration of the structure has to be chosen, e.g. if the structure is covered by armour, or by sand that is eroded only during extreme events, or not at all. It has to be decided to use containments alone or combined with reinforcement. Overall stability has to be verified for static and dynamic load situations. Possible settlement has to be anticipated. Local stability has to be addressed like slippage at the geotextile interfaces or shear deformation in the fill. Sufficient erosion resistance, filter stability, abrasion and impact strength shall be guaranteed. Furthermore, chemical reactions including effects of UV radiation and biological factors have to be taken into consideration. Overviews over relevant approaches are given in Pilarczyk (2000), Lawson (2008) or PIANC (2011). Recent research on stability and dominating factors of stacked containers has been published by Dassanayake and Oumeraci (2012a, b).

As shown by Recio-Molina and Oumeraci (2009), the most critical location with respect to the hydraulic stability is for the containers placed just below the still water level and the most critical load is the wave downrush. Deformations and finally failure are induced by the internal movement of the sand fill, leading to a gradual movement of one container out of the bond. To avoid such movements, additional reinforcement could be placed in between the containers or geosynthetic-wraparound revetments (GWR) can be built.

GWRs are sand slopes where the sand is wrapped and encapsulated with geotextiles to create a flexible revetment. A layer of geotextile is spread and sand is placed on top of it, typically between $300 \mathrm{~mm}$ and $1000 \mathrm{~mm}$ in vertical height (Fig. 19). The loose end of the geotextile is then folded back and a second geotextile layer is laid on top and the procedure is repeated. Such a slope protection can be built up to an inclination of $70^{\circ}$, forming a kind of wall. Often the GWR is covered by sand and exposed only during storm events. For riverbank protection, GWR has been combined with willow live stakes. The vegetation adds stability through the roots and provides UV protection for the fabric when sufficiently grown.

The design of GWR is still empirical. Yasuhara and Recio-Molina (2007) performed tests that showed the importance of sufficient long reinforcement length, otherwise the same failure mode occurs as with geosynthetic containers. Furthermore, the foundation of such a slope protection should be deep enough for not being threatened by scouring. Alternatively, an extra scour protection at the toe can be applied. 


\section{Autorenfassung}

Heibaum: Geosynthetics for waterways and flood protection structures - Controlling the interaction of water and soil, 2014

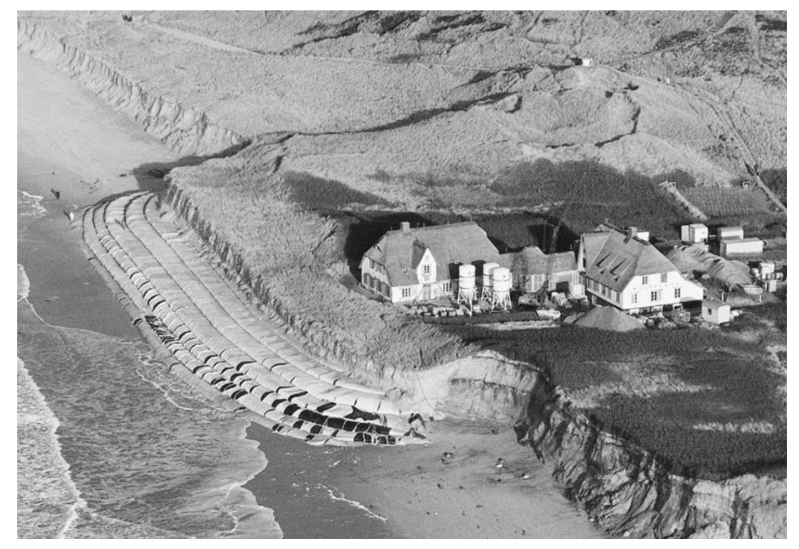

Fig. 20 Wrap-around protection, island of Sylt, Germany (CNaue).

\section{Heibaum: Geosynthetics for waterways and flood protection structures -}

Controlling the interaction of water and soil.

Geotextiles and Geomembranes 42 (2014), S. 375-393.

Moayedi et al. (2011) performed a numerical (finite element) comparison of stone walls and geotextile walls and concluded that geotextile are an optimal solution for coastal protection. The authors propose to develop reliable standard design methods for such structures which are not yet available. But on an empirical basis, reliable structures can be built as it is proven by the protection of a house at the cliff of the German island of Sylt (Fig. 20). The GWR was built in the early 1990s (Nickels and Heerten,1996) and survived several storm surges. Meanwhile the cliff retreated significantly, only at the protected area the coastline remained at the same place.

\section{Conclusions}

The design of structures for waterways and flood protection is dominated by the interaction of water and soil. To avoid detrimental effects of this interaction, it is desirable to control the hydraulic action. To achieve such control, the approach can be to separate water and soil completely, to guide the surface or the interstitial flow or to increase the resistance either by strengthening the material or by implementing protection measures. For all such approaches, solutions incorporating geosynthetics are available, some since long, some only recently developed. For separation of water and soil, impervious geosynthetic material is available, to direct surface water flow or to affect the wave regime, structures build of geosynthetic elements or incorporating geosynthetics have proven their efficiency. Groundwater and seepage water can only be controlled at the border of a soil mass because there is no possibility of interference inside the soil. But at the borders, the effects can be brought under control with the help of geosynthetic separation, filter or drainage elements. Increasing the strength can be achieved by geosynthetic reinforcement, in cases of interaction of water and soil often combined with drain, filter or protection function. For surface protection numerous answers can be found in combination with geosynthetic material. Surface erosion due to 


\section{Autorenfassung}

Heibaum: Geosynthetics for waterways and flood protection structures - Controlling the interaction of water and soil, 2014

rainfall or overflow can be hindered or at least mitigated by geosynthetics and a large number of scour countermeasures are made of or incorporating geosynthetics. So today, the interaction of water and soil is always a case for geosynthetic solutions.

\section{References}

Abuel-Naga, H.M., Pender, M.J., Bergado, D.T., 2012. Design curves of prefabricated vertical drains including smear and transition zones effects. Geotextiles and Geomembranes 32, 1-9.

ADPC - Asian Disaster Preparedness Center, 2005. Handbook on Design and Construction of Housing for Flood-prone Rural Areas of Bangladesh. Nymphea, Dhaka. http://www.adpc.net/audmp/library/housinghandbook/handbook_complete-b.pdf.

Agency, 2010. Super levee urban farm. Available from: http://www.oneprize.org/semifinalistspdf/1103a.pdf.

Alexiew, D., Raithel, M., Küster, V., Detert, O., May 31 \& June 1, 2012. 15 Years of experience with geotextile encased granular columns as foundation system. In: ISSMGE-TC 211 International Symposium on Ground Improvement IS-GI Brussels.

ANMC21, 2009. Flood and storm surge control measures e Tokyo. Asian network of major cities 21. Available from: http://www.anmc21.org/english/bestpractice/Tokyo5.html.

Anthoni, J.F., 2000. Disappearing beaches: engineering solutions. Available from: http://www.seafriends.org.nz/oceano/beacheng.htm.

Ara, 2012. The Arakawa: River of the Metropolis. Arakawa-karyu River Office. Ministry of Land, Infrastructure and Transport, Tokyo, $93 \mathrm{pp}$.

Artidteang, S., Bergado, D.T., Saowapakpiboon, J., Teerachaikulpanich, N., Kumar, A., 2011. Enhancement of efficiency of prefabricated vertical drains using surcharge, vacuum and heat preloading. Geosynthetics International 18 (1), 35-47.

ASTM 48866-D4910. Standard test method for abrasion resistance of geotextiles (sand paper/sliding block method).

BAW, 1978. Vorläufige Richtlinien für die Prüfung und Dimensionierung von textilen Filtern im Verkehrswasserbau. Bundesanstalt für Wasserbau, Karlsruhe. 


\section{Autorenfassung}

Heibaum: Geosynthetics for waterways and flood protection structures - Controlling the interaction of water and soil, 2014

Bernhardt, M., Briaud, J.L., Kim, D., Leclair, M., Storesund, R., Lim, S.G., Bea, R.G., Rogers, J.D., 2011. Mississippi river levee failures: June 2008 flood. International Journal of Geoengineering Case Histories 2 (3), 127-162. http://casehistories.geoengineer.org.

Bonaiti, G., Karimov, A., Guy Fips, P.E., 2011. Evaluation of Canal Lining Projects in the Lower Rio Grande Valley of Texas - 2011 Ratings and Analysis. Texas AgriLife Estension Service TR 412, TAMU, College Station, $40 \mathrm{pp}$.

Brauns, J., Bieberstein, A., Scheuermann, A., Reith, H., 2003. Folien als Notsicherung bei durchsickerten Deichen - nützlich oder vergeblich? Wasserwirtschaft 3, 10-15.

Brumley, J.C., 1978. A study of the landslides and their relation to engineering and planning in the Southern Districts of the Narracan Shire, Victoria. Available from: http://vro.depi.vic.gov.au/dpi/vro/wgregn.nsf/pages/wg_landwtrmgmt_degrad_narracan_ pdf/.

Buscarnera, G., di Prisco, C., 2013. Soil stability and flow slides in unsaturated shallow slopes: can saturation events trigger liquefaction processes? Géotechnique 63 (10), 801-817.

Calo, E., Sako, K., Kitamura, R., Tabata, M., 2011. Slope stability analysis with change in apparent cohesion and seepage force. In: Sawangsuriya, Soralump, Mairaing (Eds.), Unsaturated soils: theory and practice 2011-Jotisankasa. Kasetsart University, Thailand, pp. 715-720.

Cazzuffi, D., 1999. Behaviour of the Geomembrane Applied in 1959 on Contrada Sabetta Dam. In: Proceedings of Rencontres Géosynthétiques 1999, French Committee on geosynthetics (CFG), vol. 1, Bordeaux, France, Balkema, pp. 305-310.

CFEM, 2006. In: Canadian Foundation Engineering Manual, fourth ed. Canadian Geotechnical Society, pp. 343-356.

CFG (French Chapter of IGS), 2001. Guide pour la realisation de planches d'essais d'endommagement, 16 pp. Available from: www.cfg.asso.fr.

Ciavola, P., Vicinanza, D., Aristodemo, F., Contestabile, P., 2011. Large-scale morphodynamic experiments on a beach drainage system. Journal of Hydraulic Research 49 (4), 523-528.

Coastalwiki, 2008. Beach drainage. Available http://www.coastalwiki.org/wiki/Beach_drainage. 


\section{Autorenfassung}

Heibaum: Geosynthetics for waterways and flood protection structures - Controlling the interaction of water and soil, 2014

Corbett, B., Jackson, L.A., Evans, T., Restall, S., 2010. Comparison of geosynthetic materials as substrates on coastal structures - Gold Coast (Australia) and Arabian Gulf. International Conference on Coastal Engineering, ICCE 2010, China, 7 pp.

Damiani, L., Aristodemo, F., Saponieri, A., Verbeni, B., Veltri, P., Vicinanza, D., 2011. Full-scale experiments on a beach drainage system: hydrodynamic effects inside beach. Journal of Hydraulic Research 49 (Supp1.), 44-54.

Dassanayake, D.T., Oumeraci, H., September 16-19, 2012a. Effect of fill ratio and type of geotextile on the hydraulic stability of geotextile sand containers in coastal engineering.In: Eurogeo 5, Fifth European Geosynthetics Congress, Valencia, Spain.

Dassanayake, D.T., Oumeraci, H. February 20e24, 2012b. Important engineering properties of geotextile sand containers and their effect on the hydraulic stability of GSC-structures. In: Eighth international conference on coastal and port engineering in developing countries (COPEDEC), Chennai, India, pp. 1940-1951.

EAO, 2002. Recommendations for the use of lining systems on the beds and banks of waterways. Mitteilungsblatt der Bundesanstalt für Wasserbau Nr. 85. Bundesanstalt für Wasserbau, Karlsruhe, pp. 11-40.

Eckert, J.W., 1983. Design of toe protection for coastal design. In: Proceedings of Coastal Structures '83, pp. 331-341.

EN 13361:2013-11. Geosynthetic barriers e characteristics required for use in the construction of reservoirs and dams.

EN 13362:2013-11. Geosynthetic barriers e characteristics required for use in the construction of canals.

EN 16416:2013-12. Geosynthetic clay barriers e determination of water flux index - flexible wall permeameters method at constant head.

EN ISO 10318:2006-02. Geosynthetics - terms and definitions.

EN ISO 10772:2013-01-31. Geotextiles. Test method for the determination of the filtration behaviour of geotextiles under turbulent water flow conditions.

EurOtop, 2007. Wave Overtopping of Sea Defences and Related Structures: Assessment Manual- die Küste, vol. 73. EurOtop, Heft, 178 pp. 


\section{Autorenfassung}

Heibaum: Geosynthetics for waterways and flood protection structures - Controlling the interaction of water and soil, 2014

Fleischer, P., Heibaum, M., 2002. Installation of clay geosynthetic barriers under water - three years of experience. In: Zanzinger, Koerner, Gartung (Eds.), Clay Geosynthetic Barriers. Swets \& Zeitlinger, Lisse (NL), pp. 41-48.

Fleischer, P., Heibaum, M., 7-10 September 2008. Excavation of GCL lining (GBR-C) in navigation canals and dikes after several years of service. In: Fourth European Geosynthetics Conference, Edinburgh, paper no.160.

Fleischer, P., Heibaum, M., 2010. Geosynthetic clay liners (GBR-C) for hydraulic structures. In: Third International Symposium on Geosynthetic Clay Liners, Würzburg, pp. 259-268.

Fukuoka, M.; Tani, S.; Yamashita, T.; Ihara, S.; Ishizaki, H.; Takano, Y., 1990. Stability of retaining wall reinforced by continuous fibers during earthquakes. In: Geotextiles, Geomembranes and Related Products (Proceedings of Fourth ICG), pp. 27-32.

GBF, Sep/Oct 2007. Gazette Galveston Bay Foundation 18 (3), 4-5.

Giroud, J.P., 1996. Granular filters and geotextile filters. In: Proceedings Geofilters '96, Montreal, Canada, pp. 565-680.

Greenwood, J.H., Schroeder, H.F., Voskamp, V., 2012. Durability of geosynthetics. CUR Publication 243. Stichting CURNET, Gouda, 295 pp.

Gruber, J., March 2e5, 2008. Stability failure of an mse during a flood and its reconstruction thereafter. In: Proceedings of the First Pan American Geosynthetic Conference, Cancun, Mexico, pp. 768-772.

Hansbo, S., July 1976. Consolidation of Clay by Band-shaped Prefabricated Drains. Ground Engineering, Foundation Publications Ltd.

Heibaum: Geosynthetics for waterways and flood protection structures Controlling the interaction of water and soil. Geotextiles and Geomembranes 42 (2014), S. 375-393.

Haselsteiner, R., Strobl, T, Heerten, G., Werth, K., September 7-10, 2008. Overflow protection systems of flood embankments with geosynthetics. In: Proceedings of the Fouth European Geosynthetics Conference, Edinburgh (EuroGeo4), Paper No. 50. 


\section{Autorenfassung}

Heibaum: Geosynthetics for waterways and flood protection structures - Controlling the interaction of water and soil, 2014

Heerten, G., October 28-30,1987. Analogies grain filters/geotextiles filters eapplication examples in hydraulic engineering. In: Post Vienna conference on geotextiles, Singapore, pp. 224-237.

Heibaum, M., Fourie, A., Girard, H., Karunaratne, G.P., Lafleur, J., Palmeira, E.M., September 18-22, 2006. Hydraulic applications of geosynthetics. In: Kuwano, J., Kosecki, J. (Eds.), Geosynthetics (Proceedings of the Eighth International Conference on Geosynthetics (8ICG)), Yokohama, Japan, Vol. 1. Milpress, Rotterdam, pp. 76-120.

Heibaum, M., Oberhagemann, K., Faisal, M.A., Haque Shahidul, September 7-10, 2008. Geotextile bags for sole permanent bank protection. In: Fourth European Geosynthetics Conference, Edinburgh, paper No. 161.

Heibaum, M., 1998. Coastal scour stabilization using granular filter in geosynthetic nonwoven containers. Geotextiles and Geomembranes 17, 341-352.

Heibaum, M., March 1-3, 2004. Cost effective construction methods using geosynthetic containers. In: Proceedings EuroGeo3 (Third European Geosynthetics Conference), München.

Heibaum, M., August 27-31, 2012. Combining plants, natural and artificial building material for the optimal protection of banks and coasts. In: International Conference on Scour and Erosion e ICSE6, Paris, Paper No.125.

Heibaum, M., 2014. Rethinking geotextile filter design. In: Tenth International Conference on Geosynthetics, Berlin, Germany.

Highland, L.M., Bobrowsky, P., 2008. The Landslide HandbookdA Guide to Understanding Landslides: Reston.U.S. Geological Survey Circular, Virginia,1325,129 pp.

Holtz, R.D., Christopher, B.R., Berg, R.R., 1997. Geosynthetic Engineering. BiTech Publishers Ltd, Richmond.

Hornsey, W.P., Heerten, G., Jackson, L.A., Restall, S.J., 2002. Case study showing the growth and development of geotextile sand containers: an Australian perspective. Geotextiles and Geomembranes 20, 231-342.

Hornsey, W.P., Sheldrick, S.M., Carley, J.T., September 2e5, 2009. Geotextile sand containers: innovative shoreline portection systems. GIGSA GeoAfrica 2009 Conference, Cape Town.

Hosaka, T.A., Mai 13, 2011. How Fudai, Japan defied the tsunami devastation. The Huffington Post. ISO/DIS 13427:2013. Geosynthetics e abrasion damage simulation (sliding block test). 


\section{Autorenfassung}

Heibaum: Geosynthetics for waterways and flood protection structures - Controlling the interaction of water and soil, 2014

Karimov, A., Leigh, E., Guy Fips, P.E., 2009. Evaluation of canal lining projects in the lower Rio Grande valley of Texas. Texas AgriLife Estension Service TR 353. TAMU, College Station, 26 pp.

Kelsey, C., August 2005. Roads, canals: trends. GFR Magazine, 22-23.

Khay, M., Gigan, J.P., Ledelliou, M. (1990): Reinforcement with continuous thread: technical developments and design methods. In: Geotextiles, Geomembranes and Related Products (Proceedings of Fourth ICG), pp. 21-26.

Kjellmann, W., 1948. Accelerating consolidation of finegrained soils by means of card-board wicks. In: Second International Conference on Soil Mechanics and Foundation Engineering.

Lagasse, P.F., Clopper, P.E., Zevenbergen, L.W., Girard, L.G., 2007.Countermeasures to prtect bridge piers from scour. NCHRP Report 593. Transportation Research Board, Washington.

Lawson, C.R., 2008. Geotextile containment for hydraulic and environmental engineering. Geosynthetics International 15 (6), 384-427.

Lee, D., Yoo, C., Park, S., Jung, S., July 6-11, 2008. Field load tests of geogrid encased stone columns in soft ground. In: Proceedings of the 18th International Offshore and Polar Engineering Conference, Vancouver, BC, Canada.

Luettich, S.M., Giroud, J.P., Bachus, R.C., 1992. Geotextile filter design guide. Geotextiles and Geomembranes 11,355-370.

Matsushima, K., Tatsuoka, F., Mohri, Y., Aqil, U., 2008a. Shear strength and deformation characteristics of geosynthetic soil bags stacked horizontal and inclined. Geosynthetics International 15 (2), 119-135.

Moayedi, H., Huat, B.B.K., Ali, T.A.M., Bakhshipor, Z., Ebadi, M., 2011. Comparison of geotube and stone cemented wall stability as coastal protection system [case study and $2 \mathrm{~d}$ limit equilibrium and FEM modeling analysis]. Australian Journal of Basic and Applied Sciences 5 (7), 16.

Nickels, H., Heerten, G., October 1996. Building elements made of geosynthetics and sand resist north sea surf. In: Proceedings of the First European Geosynthetic Conference (EuroGeo), Maastricht, The Netherlands. 


\section{Autorenfassung}

Heibaum: Geosynthetics for waterways and flood protection structures - Controlling the interaction of water and soil, 2014

Oberhagemann, K., Sharif-Al-Kamal, Md., 2004. Geobag protection in Bangladesh. In: Fourth International Conference on Filters and Drainage in Geotechnical and Enviromental engineering, Geofilters, Stellenbosch.

Palmeira, E.M., Gardoni, M.G., 2000. Geotextiles in filtration: a state of the art review and remaining challenges. In: International Symposium on Geosynthetics - GeoEng 2000, Melbourne, Australia, pp. 85-11.

PIANC, 2011. Application of geotextiles in waterfront protection, Report no. 113, Working Group 56, PIANC, MarCom, 110 pp.

Pilarczyk, K., 2000. Geosynthetics and Geosystems in Hydraulic and Coastal Engineering. A.A. Balkema Publishers, Rotterdam, The Netherlands.

Plusquellec, H., 2004. Applications of Geosynthetics in Irrigation and Drainage Projects. ICID e International Commission on Irrigation and Drainage, New. Delhi, India, 79 pp.

Raithel, M., Kirchner, A., June 17-20, 2008. Calculation techniques and dimensioning of encased columns e design and state of the art. In: Proceedings of the Fourth Asian Regional Conference on Geosynthetics, Shanghai, China.

Raithel, M., Kirchner, A., Schade, C., Leusink, E., 2005. Foundation of constructions on very soft soils with geotextile encased columns - state of the art. In: ASCEConference Geo-frontiers 2005, Austin, USA.

Raithel, M., 1999. Zum Trag- und Verformungsverhalten von geokunststoffummantelten Sandsäulen. Schriftenreihe Geotechnik, Universität Gesamthochschule Kassel, Heft 6, Kassel, Germany.

Recio-Molina, Juan, Oumeraci, Hocine, 2009. Processes affecting the hydraulic stability of coastal revetments made of geotextile sand containers. Coastal Engineering 56 (3), 260-284.

Rohe, F.P., February 26-28, 1991. Underwater placement of PVC geomembrane. Geosynthetics '91, Atlanta, USA.

RPG, 1994. Guidelines for Testing Geotextiles for Navigable Waterways. Bundesanstalt für Wasserbau, Karlsruhe.

RPW, 2006. Richtlinie für die Prüfung von mineralischen Weichdichtungen im Verkehrswasserbau (Guidelines for the Testing of Mineral Liners in Waterways Engineering). Bundesanstalt für Wasserbau, Karlsruhe. 


\section{Autorenfassung}

Heibaum: Geosynthetics for waterways and flood protection structures - Controlling the interaction of water and soil, 2014

Sadlier, M., Restall, S., Hacong, P., Quan, P.T., 2010. Geotextile containers for coastal storm protection. In: Proceedings of the Ninth International Conference on Geosynthetics, Brazil, pp. 1277-1280.

Santi, P.M., Elifrits, C.D., 2001. Landslide stabilization using wick drains. Final Report for NCHRPidea Project 57. Transportation Research Board, Washington, USA.

Schaefer, P., 2006. Basic research on rehabilitation of aged free flow canals with geomembranes. Berichte des Lehrstuhls und der Versuchsanstalt für Wasserbau und Wasserwirtschaft, Band 106, 167 pp.

Scottish Natural Heritage, 2000. A Guide to Managing Coastal Erosion in Beach/ Dune Systems. Scottish Natural Heritage. http://www.snh.org.uk/publications/online/heritagemanagement/erosion/index.shtml.

Scotto, M., Vicari, M., September 2-5, 2009. The use of a special ballasted geocomposite filter for seabed stabilisation and other coastal engineering applications. Proceedings GIGSA GeoAfrica Conference, Cape Town.

Shirley, A.F., Francis, K.W., March 16, 1977. Techniques of landslide control using drainage. In: "How to Live with Geotechnical Risks", Symposium. Australian Geomechanics Society, Cooma.

Smoltzczyk, U. (Ed.), 2003. Geotechnical Engineering Handbook, Vol. 2. Ernst \& Sohn, Berlin, 675 pp.

Strobl, Th., Schmautz, M., Perzlmaier, S., Schäfer, P., 2002. Geomembrane-based facings of existing open canals e application, monitoring and comparison with conventional sealing systems. In: Seventh International Conference on Geosynthetics. IGS, Nice, France, pp. 723-728.

Swihart, J., Haynes, J., November 2002. Canal-lining Demonstration Project - Year 10. Final Report. U.S. Bureau of Reclamation. R-02-03.

Temple, D.M., Robinson, K.M., Ahring, R.M., Davis, A.G., 1987. Agriculture Handbook 667, Stability Design of Grass-Lined Open Channels. USDA-Agricultural Research Service.

Tsuchiya, N., 2010. Superlevee Tokyo - Edogawa City. Public Works, Edogawa City. http://www.moorga.com/wp-content/uploads/2010/09/Presentation-NTsuchiya.pdf.

Van der Meer, J., 2008. Erosion strength of inner slopes of dikes against wave overtopping. Report in the Framework of the ComCoast Project. Van Gerven, K.A.J., Akkerman, G.J., 2006. Place- 


\section{Autorenfassung}

Heibaum: Geosynthetics for waterways and flood protection structures - Controlling the interaction of water and soil, 2014

ment of smart grass reinforcement at test sections Groningen Sea Dyke. Final Report in ComCoast Workpackage 3. Development of Alternative Overtopping-Resistant Sea Defences.

Venkatraman, M., Murugesan, S., 2010. Geosynthetics in maritime and hydraulic structures e case histories in India. In: Proceedings of the Ninth International Conference on Geosynthetics, Brazil, pp. 1293-1296.

Wölfel,W.,1990.Wasserbau in den Alten Reichen. Verlag für Bauwesen, Berlin, 239 pp.

Wehr, J., Heerten, G., 2005. Geogitterummantelte Säulen - ein neues System der Baugrundverbesserung. Proceedings 5 FS-KGEO, München, Germany.

Werth, K., Heerten, G., Pries, J.K., Klompmaker, J., Sep 15-16, 2010. 20 Years experience with GCLsin dams and dykes. In: Third International Symposium on Geosynthetic Clay Liners, Würzburg, Germany, pp. 269-278.

Wittmann, L., 1980. Filtrations- und Transportphänmene in porösen Medien. Inst. für Bodenmechanik und Felsmechanik der Universität Fredericiana, Heft 86, Karlsruhe.

Yasuhara, Kazuya, Recio-Molina, Juan, 2007. Geosynthetic-wrap around revetments for shore protection. Geotextiles and Geomembranes $25(4,5), 221-232$.

Yee, T.W., Choi, J.C., March 2-5, 2008. Geotextile tube application for Ilsan Grand Bridge project, Korea. In: First Pan American geosynthetics conference, Cancun, Mexico. 